\title{
Article
}

\section{Structural state of rare earth elements in eudialyte-group minerals}

\author{
Anouk M. Borst ${ }^{1 *}$ (D), Adrian A. Finch ${ }^{1}$ (D), Henrik Friis ${ }^{2}$ (D), Nicola J. Horsburgh ${ }^{1}$, Platon N. Gamaletsos ${ }^{3,4}$ (D), \\ Joerg Goettlicher ${ }^{5}$, Ralph Steininger ${ }^{5}$ and Kalotina Geraki ${ }^{6}{ }^{10}$ \\ ${ }^{1}$ School of Earth and Environmental Sciences, University of St Andrews, North Street, St Andrews KY16 9AL, United Kingdom; ${ }^{2}$ Natural History Museum, University \\ of Oslo, Oslo, Postboks 1172, Blindern 0318 Oslo, Norway; ${ }^{3}$ Department of Materials Engineering, KU Leuven, Kasteelpark Arenberg 44, 3001 Leuven, Belgium; \\ ${ }^{4}$ Center for Electron Nanoscopy, Technical University of Denmark, 2800 Kongens Lyngby, Denmark; ${ }^{5}$ Institute for Photon Science and Synchrotron Radiation, \\ Karlsruhe Institute of Technology, Eggenstein-Leopoldshafen, Germany; and ${ }^{6}$ Science Division, Diamond Light Source, Harwell Science and Innovation Campus, \\ Didcot OX11 ODE, United Kingdom
}

\begin{abstract}
Eudialyte-group minerals (EGM) attract global interest as potential resources for high-field-strength elements (e.g. Zr, $\mathrm{Nb}$, Ta, and rare-earth elements), i.e. critical materials for modern technologies. They are particularly valued for their relative enrichment in the most critical lanthanides, i.e. $\mathrm{Nd}$ and heavy rare earth elements (Gd-Lu). However, rare earth element (REE) substitution mechanisms into the EGM structure are still poorly understood. Light and heavy REE may occupy different sites and there may be ordering and/or defect clustering in the structure. This study uses X-ray absorption spectroscopy to determine the structural state of $R E E$ in EGM from prospective eudialyte-bearing complexes. Yttrium $K$-edge and $\mathrm{Nd} L_{3}$-edge spectra were collected as proxies for heavy and light $R E E$, respectively, and compared to natural and synthetic $R E E$-bearing standards. Extended $\mathrm{X}$-ray absorption fine structure data yield best fits for $\mathrm{Y}$ in six-fold coordination with $\mathrm{Y}-\mathrm{O}$ distances of 2.24-2.32 $\AA$, and a second coordination sphere comprising Fe, Na, Ca, Si and $\mathrm{O}$ at radial distances of 3.6-3.8 $\AA$. These findings are consistent with dominant $\mathrm{Y}^{3+}$ substitution for $\mathrm{Ca}^{2+}$ on the octahedral $M 1$ site in all the samples studied, and exclude preferential substitution of $\mathrm{Y}^{3+}$ onto the smaller octahedral $Z$ site or the large low-symmetry $N 4$ site.

Using lattice strain theory, we constructed relative partitioning models to predict site preferences of lanthanides we have not measured directly. The models predict that all $R E E$ are favoured on the Ca-dominant $M 1$ site and that preferential partitioning of heavy over light $R E E$ increases in EGM containing significant $\mathrm{Mn}$ in the $M 1$-octahedral rings (oneillite subgroup). Thus, the flat $R E E$ profiles that make EGM such attractive exploration targets are not due to preferential partitioning of light and heavy REE onto different sites. Instead, local ordering of Mn- and Ca-occupied M1 sites may influence the capacity of EGM to accommodate heavy REE.
\end{abstract}

Keywords: critical metals, eudialyte-group minerals, peralkaline igneous rocks, rare earth elements, partitioning models, lattice strain theory, XANES, EXAFS, X-ray absorption spectroscopy, high-field-strength elements

(Received 7 April 2019; accepted 26 July 2019; Accepted Manuscript published online: 2 August 2019; Associate Editor: Katharina Pfaff)

\section{Introduction}

Eudialyte-group minerals (EGM) are $\mathrm{Na}-\mathrm{Ca}-\mathrm{Zr}$-cyclosilicates that accommodate many elements in their complex trigonal crystal structure. In addition to the essential constituents $\mathrm{Na}, \mathrm{Ca}, \mathrm{Zr}$ and $\mathrm{Si}$, they host significant amounts of $\mathrm{Fe}, \mathrm{Mn}, \mathrm{REE}, \mathrm{Y}, \mathrm{Nb}$, $\mathrm{Hf}, \mathrm{Ti}, \mathrm{K}, \mathrm{Sr}$ and $\mathrm{Ti}$ as well as $\mathrm{Cl}, \mathrm{F}, \mathrm{H}_{2} \mathrm{O}$ and $\mathrm{OH}$ groups (Johnsen and Grice, 1999). Consequently, the eudialyte group encompasses a wide range of minerals of varying compositions and space groups (Rastsvetaeva and Chukanov, 2012), which at present includes over 28 species accepted by the International Mineralogical Association (IMA), reported from c. 105 localities worldwide (Marks and Markl, 2017).

\footnotetext{
*Author for correspondence: Anouk M. Borst, Email: anoukborst@gmail.com This paper is part of a thematic set arising from the 3rd International Critical Metals Conference (Edinburgh, May 2019).

Cite this article: Borst A.M., Finch A.A., Friis H., Horsburgh N.J., Gamaletsos P.N., Goettlicher J., Steininger R. and Geraki K. (2020) Structural state of rare earth elements in eudialyte-group minerals. Mineralogical Magazine 84, 19-34. https://doi.org/10.1180/ mgm.2019.50
}

Eudialyte-group minerals, their alteration products and associated mineral assemblages are of significant economic interest as they provide potential low-cost resources for elements such as $\mathrm{Zr}, R E E, \mathrm{Nb}$ and $\mathrm{Ta}$. These metals have a wide variety of uses in modern technologies, ranging from durable alloys, permanent magnets, catalysts and energy-efficient lighting phosphors to rechargeable batteries, and thus crucial enablers of the clean energy and transport transition. Rare earth elements, in particular, are considered critical metals due to challenges in their supply chain and a projected growth in demand (Chakhmouradian and Wall, 2012; Hatch, 2012; European Commission, 2017; Goodenough et al., 2017; Roskill, 2018; Adamas Intelligence, 2019). Significant deposits of EGM are found in peralkaline igneous complexes such as: Ilímaussaq (Greenland); Norra Kärr (Sweden); Lovozero and Khibina (Russia); Kipawa (Canada); and Pajarito (USA) (e.g. Mariano and Mariano Jr, 2012; Sjöqvist et al., 2013; Machacek and Kalvig, 2016; Goodenough et al., 2016; Smith et al., 2016; Marks and Markl, 2017; Borst et al., 2018). Eudialyte represents a relatively low-grade ore mineral $\left(\sim 1-10\right.$ wt.\% total $R E E_{2} \mathrm{O}_{3}, \sim 1$ wt.\% of $\mathrm{Nb}_{2} \mathrm{O}_{5}$ and $<0.5$ wt.\% $\left.\mathrm{Ta}_{2} \mathrm{O}_{5}\right)$ compared to carbonatite-hosted

(C) The Author(s) 2019. This is an Open Access article, distributed under the terms of the Creative Commons Attribution licence (http://creativecommons.org/licenses/by/4.0/), which permits unrestricted re-use, distribution, and reproduction in any medium, provided the original work is properly cited. 
REE ore minerals, but their economic importance is enhanced by relatively high proportions of the more valuable (i.e. more critical) heavy rare earth elements (HREE) relative to the light rare earth elements (LREE) (Fryer and Edgar, 1977; Binnemans et al., 2018), as well as relatively low $U$ and Th contents (Schilling et al., 2011) and ease of extraction through magnetic separation (Goodenough et al., 2017; Paulick and Machacek, 2017). Recent efforts to improve the metallurgical processing of eudialyte focused on resolving issues with the formation of silica gels which hinders metal extraction. Innovative multi-step leaching techniques have been developed and promise potential for upscaling, though economic viability has yet to be demonstrated at industry scales (Stark et al., 2016; Balomenos et al., 2017; Davris et al., 2017; Voßenkaul et al., 2017).

At the heart of eudialyte's commercial value is its relatively flat chondrite-normalised REE profile (Chakhmouradian and Wall, 2012, Fryer and Edgar, 1977). Partitioning of REE in minerals typically produces parabolic or curved profiles (due to partitioning behaviour as a function of ionic radius, e.g. Blundy and Wood, 2003) and the unusually flat to HREE-enriched profiles in EGM hints at substitutions into multiple sites, site ordering and/or defect clustering. Furthermore, the open literature is inconsistent as to whether REE substitute on the $\mathrm{Na}, \mathrm{Ca}$ or $\mathrm{Zr}$ sites, or a combination of these (Johnsen and Grice, 1999; Johnsen et al., 2001; Rastsvetaeva, 2007; Pfaff et al., 2008; Möller and Williams-Jones, 2016). Such considerations are more than academic - EGM deposits are commonly altered (Mitchell and Liferovich, 2006; Borst et al., 2016; Möller and Williams-Jones, 2017; Estrade et al., 2018; van de Ven et al., 2019) and some replacement processes are topotactic (i.e. retaining structural templates from the primary structure to the secondary). Furthermore, the silica-gels that form during eudialyte dissolution (e.g. Voßenkaul et al., 2017; Davris et al., 2017) may preserve structural states from the original eudialyte. There is therefore a commercial imperative that $R E E$ substitution in eudialyte is fully understood.

Here we use X-ray absorption spectroscopy (XAS), i.e. XANES (X-ray absorption near-edge structure) and EXAFS (extended $\mathrm{X}$-ray absorption fine structure) to probe the local coordination environment of REE in eudialyte-group minerals. We measure $\mathrm{Y} K$-edge and $\mathrm{Nd} L_{3}$-edge absorption spectra as proxies for the heavy and light $R E E$, respectively. The data are used to quantify $R E E$ coordination numbers and nearest-neighbour bond distances to provide a more detailed understanding of $R E E$ substitution mechanisms in the EGM crystal structure. We analyse the results using lattice strain partitioning models and extrapolate the partitioning behaviour for the lanthanides we have not measured directly. In doing so, we provide insights into the flat-to-inclined heavy $R E E$ profiles that make eudialyte such an attractive resource.

\section{Crystal structure of the eudialyte group}

Minerals of the trigonal eudialyte aristotype are composed of a heteropolyhedral framework of interlayered three- and ninemembered rings of $\mathrm{Si}$ tetrahedra $\left[\mathrm{Si}_{3} \mathrm{O}_{9}\right.$ and $\left.\mathrm{Si}_{9} \mathrm{O}_{27}\right]$ and sixmembered rings of edge-shared $\mathrm{Ca}$ octahedra $\left[\mathrm{Ca}_{6} \mathrm{O}_{24}\right]$, joined together by isolated $\mathrm{Zr}$ octahedra. The layers follow a TZTM ordering along the $c$ axis, where $\mathrm{T}$ denotes the three- and ninemembered $\left[\mathrm{Si}_{3} \mathrm{O}_{9}\right]$ and $\left[\mathrm{Si}_{9} \mathrm{O}_{27}\right]$ rings, $\mathrm{Z}$ denotes layers of discrete $\mathrm{Zr}$ and/or Ti octahedra and $\mathrm{M}$ represents layers of six-membered rings of Ca octahedra (Rastsvetaeva, 2007). Spaces within the framework are filled with polyhedra of alkali, alkaline-earth and transitional-metal cations (valences +1 to +6 ) and volatile groups $\left(\mathrm{Cl}^{-}, \mathrm{F}^{-}, \mathrm{OH}^{-}, \mathrm{SO}_{4}^{-}, \mathrm{H}_{2} \mathrm{O}\right.$ and $\left.\mathrm{H}_{3} \mathrm{O}^{+}\right)$. Iron and manganese predominantly occupy 4- or 5-coordinated M2 sites, respectively, in planar squares or five vertex-pyramids between the sixmembered rings (Guiseppetti et al., 1971; Johnsen and Grice, 1999; Rastsvetaeva and Chukanov, 2012; Rastsvetaeva, 2007). Ordering of elements on the various sites gives rise to a wide range of EGM compositions and structural hettotypes, predominantly within the $R 3 m, R \overline{3} m$ and $R 3$ space groups (Rastsvetaeva, 2007, Rastsvetaeva and Chukanov, 2012).

The IMA-accepted formula for the eudialyte group is: $N_{15-16}[M 1]_{6}[M 2]_{3}[M 3][M 4] Z_{3} \mathrm{Si}_{24} \mathrm{O}_{66-73}(\Theta)_{0-9}(X)_{2}$, where: $N=\mathrm{Na}^{+}$, $\mathrm{K}^{+}, \mathrm{Sr}^{2+}, \mathrm{Ca}^{2+}, R E E^{3+}, \square$ (vacancy), $\mathrm{Ba}^{2+}, \mathrm{Mn}^{2+}$ or $\mathrm{H}_{3} \mathrm{O}^{+}$; $M 1=\mathrm{Ca}^{2+}, R E E^{3+}, \mathrm{Mn}^{2+}, \mathrm{Fe}^{2+}, \mathrm{Na}^{+}, \mathrm{Sr}^{2+} ; \mathrm{M} 2=\mathrm{Fe}^{2+}, \mathrm{Mn}^{2+}$, $\mathrm{Na}^{+}, \square, \mathrm{H}_{3} \mathrm{O}^{+}, \mathrm{Zr}^{4+}, \mathrm{Ta}^{5+}, \mathrm{Ti}^{4+}, \mathrm{K}^{+}, \mathrm{Ba}^{2+}$ or $\mathrm{Fe}^{3+} ; \mathrm{M} 3 / 4=\mathrm{Si}^{4+}$, $\mathrm{Al}^{3+}, \mathrm{Nb}^{5+}, \mathrm{Ti}^{4+}, \mathrm{W}^{6+}$ or $\mathrm{Na}^{+}, Z=\mathrm{Zr}^{4+}, \mathrm{Hf}^{4+}, \mathrm{Ti}^{4+}$ or $\mathrm{Nb}^{5+}$; $\Theta=\mathrm{H}_{2} \mathrm{O}, \mathrm{OH}^{-}, \mathrm{O}^{2-}, \mathrm{CO}_{3}^{2-}, \mathrm{SO}_{4}^{2-}$ or $\mathrm{SiO}_{4}^{4-}$; and $\mathrm{X}=\mathrm{Cl}^{-}, \mathrm{F}^{-}$or $\mathrm{OH}^{-}$(Johnsen et al., 2003).

Empirical formulae are calculated on the basis of 29 cations for the sum of $\mathrm{Si}, \mathrm{Al}, \mathrm{Zr}, \mathrm{Ti}, \mathrm{Hf}, \mathrm{Nb}, \mathrm{W}$ and Ta. At present, 200 years after eudialyte was first reported (Stromeyer, 1819), the eudialyte group comprises 28 independent IMA-approved mineral species, and new ones are described regularly (e.g. Rastsvetaeva et al., $2015,2017)$. It is worth noting that the number of crystallographically non-equivalent sites increases in non-centrosymmetric space groups. Common species of EGM include eudialyte sensu stricto, kentbrooksite, ferrokentbrooksite, alluaivite, oneillite and $(\mathrm{Mn}-)$ raslakite (Table 1 ), with natural samples showing solid solution between end-members.

Of the many trace elements that substitute into eudialyte-group minerals, the $R E E$ are particularly significant, and can reach up to 10 wt.\% $R E E_{2} \mathrm{O}_{3}$ (Grice and Gault, 2006). However, their exact location has been unclear. In eudialyte s.s. the REE are inferred to substitute for $\mathrm{Ca}$ on the $\mathrm{M} 1$ site, while in kentbrooksite, oneillite and raslakite, the REE are inferred to occupy both the $N$ and $M 1$ sites. Johnsenite-(Ce) and zirsilite-(Ce) are the only 'true' $R E E$-species, where REE (dominantly light) dominate the N4 site (Table 1). No direct analysis of lanthanide substitution has been performed on the more common EGM members. Furthermore, it is unclear whether the light and heavy REE partition into different sites as a function of their varying ionic radii.

\section{Approach and hypothesis}

Using XAS we perform the first direct measurements to probe the coordination sphere of $\mathrm{Y}$ and $\mathrm{Nd}$ atoms in the structure of common EGM, particularly to test whether heavy and light $R E E$ occupy different structural sites. If both $\mathrm{Y}^{3+}$ and $\mathrm{Nd}^{3+}$ substitute for $\mathrm{Ca}^{2+}$ on the $\mathrm{M} 1$ site, the data will yield best fits in 6-fold coordination with interatomic bond distances approaching $2.35 \AA$ A. Significantly longer bond distances (c. $2.6 \AA$ ) and larger mean-square relative displacement Debye-Waller factors $\left(\sigma^{2}\right.$, attenuation of X-ray scattering, indicative of greater structural disorder) would imply that REE are occupying the larger, low symmetry, multi-coordinated $N$ sites. Smaller bond distances, DebyeWaller factors and a second coordination sphere fitting to $6 \mathrm{Si}$ and $10 \mathrm{Na}$ between $3.6-3.8 \AA$ may suggest that $\mathrm{Y}(0.9 \AA)$ and, by inference, similarly sized heavy $R E E$, substitute for $\mathrm{Zr}$ on the octahedral $Z$ site. The presence of $R E E$ in multiple sites would be inferred from bond distances inconsistent with any of the sites and large Debye-Waller factors inconsistent with a single site. Additional information on the nature and distance of elements in the second coordination sphere are extracted from the EXAFS signal to further constrain the local structure of REE in EGM. 
Table 1. IMA approved members of the Eudialyte Group mentioned in the text.

\begin{tabular}{|c|c|c|c|c|c|c|c|c|c|c|}
\hline Mineral & Space gr. & $N$ & $M 1(\mathrm{a} / \mathrm{b})^{\mathrm{b}}$ & $M 2^{c}$ & M3 & M4 & $Z$ & $\mathrm{Si}_{24} \mathrm{O}_{66-73}$ & $\Theta$ & $X$ \\
\hline Eudialyte & R3m & $\mathrm{Na}_{15}$ & $\mathrm{Ca}_{6}$ & ${ }^{I V} \mathrm{Fe}_{3}$ & Si & Si & $\mathrm{Zr}_{3}$ & $\mathrm{Si}_{24} \mathrm{O}_{73}$ & $\left(\mathrm{O}, \mathrm{OH}, \mathrm{H}_{2} \mathrm{O}\right)_{3}$ & $(\mathrm{Cl}, \mathrm{OH})_{2}$ \\
\hline Ferrokentbrooksite & $\mathrm{R} 3 \mathrm{~m}$ & $\mathrm{Na}_{15}$ & $\mathrm{Ca}_{6}$ & ${ }^{\mathrm{IV}} \mathrm{Fe}_{3}$ & $\mathrm{Nb}$ & Si & $\mathrm{Zr}_{3}$ & $\mathrm{Si}_{24} \mathrm{O}_{73}$ & $\left(\mathrm{O}, \mathrm{OH}, \mathrm{H}_{2} \mathrm{O}\right)_{3}$ & $(\mathrm{~F}, \mathrm{Cl})_{2}$ \\
\hline Kentbrooksite & $\mathrm{R} 3 \mathrm{~m}$ & $\mathrm{Na}_{15}$ & $\mathrm{Ca}_{6}$ & $\mathrm{v}_{\mathrm{Mn}_{3}}$ & $\mathrm{Nb}$ & Si & $\mathrm{Zr}_{3}$ & $\mathrm{Si}_{24} \mathrm{O}_{73}$ & $\left(\mathrm{O}, \mathrm{OH}, \mathrm{H}_{2} \mathrm{O}\right)_{3}$ & $(\mathrm{~F}, \mathrm{Cl})_{2}$ \\
\hline Zirsilite-(Ce) & $\mathrm{R} 3 \mathrm{~m}$ & $\mathrm{Na}_{12} \mathrm{Ce}_{3}{ }^{\mathrm{a}}$ & $\mathrm{Ca}_{6}$ & $\mathrm{v}_{\mathrm{Mn}_{3}}$ & $\mathrm{Nb}$ & $\mathrm{Si}$ & $\mathrm{Zr}_{3}$ & $\mathrm{Si}_{24} \mathrm{O}_{73}$ & $(\mathrm{OH})_{3}\left(\mathrm{CO}_{3}\right)$ & $\mathrm{H}_{2} \mathrm{O}$ \\
\hline Johnsenite-(Ce) & $\mathrm{R} 3 \mathrm{~m}$ & $(\mathrm{Na}, \square)_{12}(\mathrm{Ce}, \mathrm{Na})_{3}$ & $\mathrm{Ca}_{6}$ & $\mathrm{v}_{\mathrm{Mn}_{3}}$ & W & Si & $\mathrm{Zr}_{3}$ & $\mathrm{Si}_{24} \mathrm{O}_{73}$ & $\mathrm{CO}_{3}$ & $(\mathrm{OH})_{2}$ \\
\hline Alluaivite & $\mathrm{R} \overline{3} \mathrm{~m}$ & $\mathrm{Na}_{16}$ & $\mathrm{Ca}_{6}$ & ${ }^{\mathrm{IV}} \mathrm{Na}_{3}$ & $\mathrm{Si}$ & $\mathrm{Si}$ & $\mathrm{Ti}_{3}$ & $\mathrm{Si}_{24} \mathrm{O}_{73}$ & $2 \mathrm{H}_{2} \mathrm{O}$ & $\mathrm{Cl}$ \\
\hline Oneillite & R3 & $\mathrm{Na}_{15}$ & $\mathrm{Mn}_{3} \mathrm{Ca}_{3}$ & $\mathrm{~V}_{\mathrm{Fe}_{3}}$ & $\mathrm{Nb}$ & $\mathrm{Si}$ & $\mathrm{Zr}_{3}$ & $\mathrm{Si}_{24} \mathrm{O}_{73}$ & $\left(\mathrm{O}, \mathrm{OH}, \mathrm{H}_{2} \mathrm{O}\right)_{3}$ & $(\mathrm{OH}, \mathrm{Cl})_{2}$ \\
\hline Raslakite & R3 & $\mathrm{Na}_{15}$ & $\mathrm{Ca}_{3} \mathrm{Fe}_{3}$ & $\mathrm{~V}_{\mathrm{Na}_{3}}$ & $\mathrm{Si}$ & $\mathrm{Si}$ & $\mathrm{Zr}_{3}$ & $\mathrm{Si}_{24} \mathrm{O}_{73}$ & $\left(\mathrm{O}, \mathrm{OH}, \mathrm{H}_{2} \mathrm{O}\right)_{3}$ & $(\mathrm{Cl}, \mathrm{OH})_{2}$ \\
\hline (Mn,Ca)-ordered eudialyte & R3 & $\mathrm{Na}_{15}$ & $\mathrm{Ca}_{3} \mathrm{Mn}_{3}$ & $\mathrm{~V}_{\mathrm{Na}_{3}}$ & Si & $\mathrm{Si}$ & $\mathrm{Zr}_{3}$ & $\mathrm{Si}_{24} \mathrm{O}_{73}$ & $\left(\mathrm{O}, \mathrm{OH}, \mathrm{H}_{2} \mathrm{O}\right)_{3}$ & $(\mathrm{OH})_{2}$ \\
\hline Aqualite & R3 & $\mathrm{Na}_{5}\left(\mathrm{H}_{3} \mathrm{O}\right)_{8} \square$ & $\mathrm{Ca}_{3} \mathrm{Ca}_{3}$ & ${ }^{\mathrm{IV}} \square, \mathrm{Na}_{3}$ & $\mathrm{Si}$ & $\mathrm{Si}$ & $\mathrm{Zr}_{3}$ & $\mathrm{Si}_{24} \mathrm{O}_{66}$ & $(\mathrm{OH})_{9}$ & $\mathrm{Cl}$ \\
\hline
\end{tabular}

${ }^{\mathrm{a}}$ The REE are on the $\mathrm{N} 4$ subsite; ${ }^{\mathrm{b}}$ members of the $\mathrm{R} 3$ space groups (oneillite sub-group) have two ordered $M 1$ subsites, $M 1 \mathrm{a}$ and $M 1 \mathrm{~b}$, respectively, in the $M 1_{6} \mathrm{O}_{36}$ rings; ${ }^{\mathrm{C}} M 2$ site coordination is indicated by the superscript.

\section{Methods and materials}

\section{Sample preparation}

X-ray absorption spectra were collected for EGM from five localities; Ilímaussaq, the Narsaarsuk ${ }^{1}$ pegmatite (Greenland); Norra Kärr (Sweden); Kipawa (Canada); and Lovozero (Russia). Sample details and compositional data are provided in Supplementary 1, Table S1 and Table S2 deposited with the Principal Editors of Mineralogical Magazine (see below). The samples are dominantly eudialyte s.s. with minor kentbrooksite components (Ilímaussaq, Narsaarsuk, Norra Kärr), a (Mn,Ca)-ordered variety (Lovozero) and a low Fe, high Ca-Y variety (Kipawa). Most EGM display $L R E E$-enriched rare-earth profiles with flat HREE patterns (Supplementary 1). The most HREE-(particularly Y) enriched sample derives from Kipawa, consistent with published EGM compositions from that complex (Johnsen and Grice, 1999). For simplicity we refer to all studied EGM as 'eudialyte'. In addition, we measured a selection of natural and synthetic REE-standards in which the REE occupy various coordination states and symmetry environments (Tables 2, S1) because few XANES data for $R E E$-(bearing) minerals are available in the literature. Microcrystalline Y-doped monazite- $(\mathrm{Nd})$ was synthesised at the University of St Andrews following procedures described by Friis (2009) (Supplementary 1). Synthetic crystals of Nd-doped $\mathrm{YPO}_{4}$ were provided by Lynn Boatner, ORNL (Boatner, 2002). Excluding the gem-quality zircon and a diamond blank, samples and standards were ground under ethanol in an agate mortar and checked for phase purity by powder X-ray diffraction (XRD) (University of St Andrews) prior to XAS measurements. Samples were measured as powders or crystals mounted on KAPTON( tape. Single-cation $\mathrm{Y}$ and $\mathrm{Nd}$ solutions (prepared from $\mathrm{Y}_{2} \mathrm{O}_{3}$ in 2\% nitric acid, Inorganic Ventures CGY1) were measured after injection into a metallic liquid-sample cell sealed between KAPTON@ tape.

\section{XAS data collection}

$\mathrm{X}$-ray absorption spectroscopy measurements were carried out at the I18 micro-focus beamline at the Diamond Light Source, a $3 \mathrm{GeV}$ 3rd generation synchrotron facility (Didcot, United Kingdom), and at the SUL-X beamline of the KIT Karlsruhe Light Source, a $2.5 \mathrm{GeV}$ storage ring with typical electron currents of 100 to $150 \mathrm{meV}$ (Karlsruhe Institute for Technology, Germany). The I18 beamline is designed for high spatial resolution analyses of

${ }^{1}$ Previously spelled Narssârssuk heterogeneous samples within the 2.05-20.5 keV energy range, and set up for $\mu$-X-ray fluorescence mapping, $\mu$-XRD, $\mu$-XANES and $\mu$-EXAFS (see Mosselmans et al., 2009). The SUL-X beamline is set up for the same micro-methods as I18 and uses a 27 pole Wiggler radiation source to cover an energy range of 2.4 to $20 \mathrm{keV}$. Details of the set-up and measurements at the SUL-X beamline are provided in Supplementary 1.

All measurements were run at room temperature. The EGM samples and standards with medium to low $\mathrm{Y}$ and $\mathrm{Nd}$ contents were measured in fluorescence mode, whereas REE-rich standards were measured in transmission mode. A $3 \mu \mathrm{m} \times 3 \mu \mathrm{m}$ focussed beam was employed at I18. At SUL-X measurements were run using a moderately focused beam ranging in size from $150 \mu \mathrm{m}$ by $250 \mu \mathrm{m}$ to $50 \mu \mathrm{m} \times 50 \mu \mathrm{m}$ (depending on count rates). The energy range was set to include both the X-ray absorption nearedge structure (XANES) and extended X-ray absorption fine structure (EXAFS) regions for the $\mathrm{Y} K$-edge $(17,038 \mathrm{eV})$ and the $\mathrm{Nd} L_{3}$-edge $(6208 \mathrm{eV})$. Yttrium was chosen because it can be analysed on the $K$-edge, which has no significant interference from absorption edges of other elements over the measured energy range, and $\mathrm{Nd}$ because natural materials contain no Pm, allowing a longer $k$ range in the EXAFS spectrum than other lanthanides.

At I18, Mn (K-edge at $6539 \mathrm{eV})$ and $\mathrm{Zr}$ (K-edge at 17,998 eV) metal foils were measured for the energy calibration of the $\mathrm{Nd}$ $L_{3}$-edge spectra $(6208 \mathrm{eV})$ and $\mathrm{Y} K$-edge spectra $(17,038 \mathrm{eV})$, respectively. At SUL-X, energy calibration was done by running $\mathrm{Y}$ and $\mathrm{Mn}$ metal foils between measurements. Detector count rates were checked to ensure measurement within the linear range. The width of the energy interval defining elemental peak areas was optimised to exclude influence from fluorescence signals of neighbouring elements. The $\mathrm{Nd} L_{3}$-edge XAS region also contains the Ce $L_{2}$-edge at $6164 \mathrm{eV}$ (in the pre-edge region) and the $\operatorname{Pr} L_{2}$-edge at $6440 \mathrm{eV}$ in the EXAFS. Despite tight windowing of the secondary $\mathrm{Nd} L \alpha \mathrm{X}$-rays (minimising the response from $\mathrm{Ce} L_{2}$ and $\operatorname{Pr} L_{2}$ ) and insertion of Al-foils in the path of the $\mathrm{X}$-ray beam to filter out lower energy X-rays, $L_{2}$-edge absorption peaks for $\mathrm{Ce}$ and $\mathrm{Pr}$ remain visible in most samples. Due to the interference of both $\mathrm{Ce}_{2}$ and $\operatorname{Pr} L_{2}$ over the relevant $k$ range, the $\mathrm{Nd}$ scans were considered unsuitable for quantitative EXAFS refinement. Samples analysed on both beamlines showed no significant differences in spectra.

\section{XAS data processing}

Data were processed using the Athena and Artemis Demeter Perl packages for XAS analyses following the IFEFFIT program (Ravel 
and Newville, 2005). XAS spectra were normalised to the X-ray source intensity $\left(I_{\mathrm{o}}\right)$ and the absorption edge step height to yield $\mu(E)$, and the absorption edge set to the maximum of the first derivative. Backgrounds were removed using the $A U T O B K$ background subtraction algorithm (Newville, 2001), using spline $k$ ranges of 0 to 11 and a $R_{\mathrm{bkg}}$ value of $1.0-1.1$, but carefully avoiding the Ce $L_{2}$-edge absorption peak in the pre-edge background of the $\mathrm{Nd}$ absorption spectra. Duplicate runs (typically $n=4$ ) were merged to improve signal-to-noise ratios. EXAFS oscillations and phase-shifted Fourier transforms providing radial distribution functions were processed and fitted in Artemis (Ravel and Newville, 2005). Theoretical scattering paths were calculated using the integrated ATOMS and FEFF6 software using diffraction-based crystal structures available from the American Mineralogist Crystal Structure Database (Downs and Hall-Wallace, 2003).

The fitted $k$ range and $R$ range for eudialyte was $2.5-10 \AA^{-1}$ and $1-4 \AA$, respectively, to yield comparable fitting parameters and the same number of independent variables supported by the data $(N=2 \Delta k \Delta R / \pi)$. For each fit, the number of fitted parameters $(P)$ are kept to a minimum to ensure a determinacy $(N / P)$ above 2. Refined parameters include the energy offset $\left(\Delta E_{0}\right.$ in $\left.\mathrm{eV}\right)$, the mean interatomic distance between the absorber and the scatterer atoms $\left(R_{\mathrm{Y}-\mathrm{O}}, R_{\mathrm{Y}-\mathrm{Si}}, R_{\mathrm{Y}-\mathrm{Fe}}, R_{\mathrm{Y}-\mathrm{Ca}}\right.$, etc in $\left.\AA\right)$ and the mean-square relative displacement Debye-Waller factor per scatterer $\left(\sigma^{2}\right.$ in $\left.\AA^{-2}\right)$. The amplitude reduction factor $\left(S_{0}^{2}\right)$ was determined from a three-shell EXAFS fit for the $\mathrm{Y}_{2} \mathrm{O}_{3}$ reference powder by fixing the coordination numbers for each path $(1.00 \pm 0.18, R$ factor 0.024$)$. Coordination numbers $(\mathrm{CN})$ were only refined in initial first shell fits, and subsequently fixed to optimal values to reduce the number of variables and maintain a determinacy of $>2$. Similarly, $\Delta E_{0}$ was determined from the firstshell fit and subsequently fixed in the second-shell refinements. All XANES and EXAFS data are given in Tables S3 and S4.

\section{Structural model for REE in EGM}

For the eudialyte Y EXAFS refinements we consider three possible sites as credible locations for the REE: (1) the octahedral M1 site; (2) the low-symmetry 9-fold N4 site; or (3) the octahedrally Zr-dominant $Z$ site. The Fe or Mn dominated M2 site is not considered a viable location for the REE because of its 4-fold (planar square) or 5-fold coordination; we know of no synthetic or natural solid in which REE adopt such a coordination state. Rather than attempting $a b$ initio refinement of the Y EXAFS in eudialyte, we modelled the data in turn from the starting point of each of the three possible coordination spheres $(M 1, N 4$ and $Z)$ and then allowed the parameters to refine. XRD suggests that the $M 1$ site is a slightly distorted and flattened octahedron with $2 \mathrm{O}$ at $\sim 2.31$ and $4 \mathrm{O}$ at $\sim 2.37 \AA$ (Table 3, illustrated in Fig. 1b, Johnsen and Grice, 1999). The second candidate for REE and Y substitution is the low symmetry $N$ site, of which there are up to five sub-sites (Johnsen and Grice, 1999; Rastsvetaeva, 2007) with varying coordinations (6 to 10), and much larger $\mathrm{Na}-\mathrm{O}$ (and $\mathrm{Na}-\mathrm{Cl}$ ) bond distances of $\sim 2.5-2.8 \AA$ (Fig $1 d$ ). Of all $N$ sites, XRD suggests the $N 4$ site is the most likely host for REE, Sr, K or Mn (Johnsen and Grice, 1999). The third option, the $Z$ site, is a near regular octahedron comprising 6 oxygens at a distance of $2.08 \AA$ from the central $\mathrm{Zr}$ atom (Fig 1c), each shared with a $\mathrm{Si}$ atom from a corner-linked $\left[\mathrm{SiO}_{4}\right]$-tetrahedron. XRD-inferred bond distances per site (for eudialyte s.s.) are listed in Table 3. Theoretical scattering paths for the various sites were calculated using FEFF6 from structural models for eudialyte from the Ilímaussaq complex and the Narsaarsuk pegmatite from Johnsen and Grice (1999). Crystallographic data (.cif) files were rewritten to full site occupation to allow FEFF6 path calculations. Only single scattering paths are considered.

\section{Results}

\section{$Y$ K-edge XANES}

Normalised Y $K$-edge XANES for the eudialyte samples and standards are shown in Fig. $2 a$. All standards display sharp white lines at 17,050-17,052 eV (edge energy determined as the maximum of 1st derivative, indicated with a black line and arrow in Fig. 2), with a narrow peak at $\sim 17,056 \mathrm{eV}$ (feature B, Fig. $2 a$ ). The standard spectra show variations in the position and relative height of absorption features labelled A to D (Fig. 2), reflecting different structural states for Y. We observe a potential systematic shift in the position and shape around feature $\mathrm{D}$ as a function of coordination number $(\mathrm{CN})$, with the middle of the peak(s) moving to lower energy with increasing CN. From 6- to 9-fold coordinations, the magnitude of this shift is $\sim 10 \mathrm{eV}$, i.e. the peak is centred at $17,110 \mathrm{eV}$ for phases with $\mathrm{Y}$ in 6-coordinated sites, at $17,107 \mathrm{eV}$ for phases with mixed $\mathrm{Y}$ coordinations of $6-7-8$, at $17,104 \mathrm{eV}$ for 8 -fold $\mathrm{Y}$ and at $17,100 \mathrm{eV}$ for phases with $\mathrm{Y}$ in 9-fold coordination (Fig 2b). Allanite-(Ce), with $\mathrm{Y}$ in lowsymmetry 9-11-fold sites, is an outlier to this trend. Furthermore, Y XANES for standards in which Y occupies higher point symmetry sites (i.e. zircon, $\mathrm{YPO}_{4}-\mathrm{Nd}, \mathrm{NdPO}_{4}-\mathrm{Y}$ and $\mathrm{Y}_{2} \mathrm{O}_{3}$ ) exhibit more pronounced absorption features, in particular a double- or triple-peak around feature D (grey arrows in Fig. 2b), or a shoulder after feature C (Fig. 2a).

The Y K-edge absorption energy for eudialyte is $17,050 \mathrm{eV}$ (maximum of 1st derivative). The spectra reveal unique XANES features compared to the measured standards. With one exception (AF/99/193, Fig $2 b$ ), all eudialyte display a characteristic double-peaked XANES profile, with a small first bump at 17,053 (feature A), which is not identified in the standards, a broad maximum at $17,061 \mathrm{eV}$ (feature C) and a minor downward kink at $17,056 \mathrm{eV}$ (feature B, i.e. where most of the standard XANES have their maxima). The eudialyte spectra furthermore show a broad peak at $17,110 \mathrm{eV}$ (feature D, Fig $2 d$ ), representing the first EXAFS oscillation in $k$ space. The position, height and width of feature $\mathrm{D}$ in the eudialyte spectra are most consistent with the XANES of standards in which $\mathrm{Y}$ is inferred to be in 6-fold coordination (Fig. $2 b, d$ ). Further information about the structural state of Y in eudialyte is derived from quantitative refinements of the EXAFS parts of the spectra described in the discussion.

\section{$N d L_{3}$-edge XANES}

The standards exhibit $\mathrm{Nd} L_{3}$-XANES spectra with sharp white lines at $6213 \mathrm{eV}$, narrow peaks, and minor variations in the relative heights and positions of identified XANES features (Fig. 3a). Cerium $L_{2}$-edge absorption features appear in the pre-edge region of all natural REE samples. The latter display notable variations in the relative heights of the $\mathrm{Ce}^{3+}, \mathrm{Ce}^{4+}$ and $\mathrm{Nd}^{3+}$ absorption peaks, reflecting natural variations in $\mathrm{Ce}^{3+} / \mathrm{Ce}^{4+}$ and $\mathrm{Ce} / \mathrm{Nd}$ ratios (Fig 3). Higher symmetry standards ('yttrofluorite', xenotime $\left(\mathrm{YPO}_{4}{ }^{-}\right.$ $\mathrm{Nd}$ ), Nd-aqueous) show more pronounced Nd XANES features 
Table 2. Eudialyte samples and standards measured in this study.

\begin{tabular}{|c|c|c|c|c|}
\hline Group & Mineral & Formula & Locality & Sample ID \\
\hline \multicolumn{5}{|l|}{ EGM samples } \\
\hline \multirow[t]{5}{*}{ Zirconosilicate } & Eudialyte s.l. & $\mathrm{Na}_{15} \mathrm{Ca}_{6}(\mathrm{Fe}, \mathrm{Mn})_{3} \mathrm{Zr}_{3}(\mathrm{Si}, \mathrm{Nb}) \mathrm{Si}_{24} \mathrm{O}_{66-73} \cdot\left(\mathrm{OH}_{\mathrm{O}_{-}} \mathrm{Cl}_{2}\right)$ & Norra Kärr, Sweden & MoOBmt, EGM11_PG \\
\hline & & & Narsaarsuk pegmatite, Greenland & $\mathrm{NJH} / 16 / 44$ \\
\hline & & & Kringlerne, Ilímaussaq, Greenland & $\mathrm{AF} / 99 / 193,109211$ \\
\hline & & & Lovozero, Russia & Sos033 \\
\hline & & & Kipawa, Canada & 1051KIP \\
\hline \multicolumn{5}{|l|}{ Standards } \\
\hline \multirow[t]{8}{*}{ Silicate } & A1 (britholite-group) & $(\mathrm{Ca}, R E E)_{5}\left(\mathrm{SiO}_{3}\right)_{3}(\mathrm{OH}, \mathrm{F})_{2}$ & Ilímaussaq, Greenland & $\mathrm{A} 1 \_\mathrm{HF}$ \\
\hline & Steenstrupine & $\mathrm{Na}_{14} R E E_{6}(\mathrm{Mn}, \mathrm{Fe})_{3}(\mathrm{Zr}, \mathrm{Th})(\mathrm{OH})_{2}\left(\mathrm{PO}_{4}\right)_{7} \mathrm{Si}_{12} \mathrm{O}_{36} \cdot 3 \mathrm{H}_{2} \mathrm{O}$ & Ilímaussaq, Greenland & $\mathrm{HF} / \mathrm{B} 32 / \mathrm{Str}$ \\
\hline & Rinkite-(Ce) & $(\mathrm{Na}, \mathrm{Ca})_{3}(\mathrm{Ca}, \mathrm{Ce})_{4}(\mathrm{Ti}, \mathrm{Nb})\left(\mathrm{Si}_{2} \mathrm{O}_{7}\right)_{2}(\mathrm{O}, \mathrm{F})_{4}$ & Ilímaussaq, Greenland & 520713_Rnk \\
\hline & Nacareniobsite-(Ce) & $\mathrm{Na}_{3} \mathrm{Ca}_{3} R E E N b\left(\mathrm{Si}_{2} \mathrm{O}_{7}\right)_{2} \mathrm{OF}_{3}$ & Ilímaussaq, Greenland & 109212 \\
\hline & Zircon & $\mathrm{ZrSiO}_{4}$ & Paatusoq, Greenland & $\mathrm{AF} / 13 / 10$ \\
\hline & & & Cambodia (annealed blue gem) & BlueZrc \\
\hline & & & Ambohimirahavavy, Madagascar & MAD238 \\
\hline & Allanite-(Ce) & $(\mathrm{Ce}, \mathrm{Ca}, \mathrm{Y})_{2}\left(\mathrm{Al}, \mathrm{Fe}^{3+}\right)_{3}\left(\mathrm{SiO}_{4}\right)_{3}(\mathrm{OH})$ & Amherst, Virginia, USA & GLAHM134365 \\
\hline Fluoride & 'Yttrofluorite' & $(\mathrm{Ca}, \mathrm{Y}) \mathrm{F}_{2}$ & Hundholmen, Tysfjord, Norway & KNR8727 \\
\hline \multirow[t]{5}{*}{ Phosphate } & Fluorapatite & $\mathrm{Ca}_{5}\left(\mathrm{PO}_{4}\right)_{3} \mathrm{~F}$ & Ilímaussaq, Greenland & $\mathrm{AF} / 07 / 11$ \\
\hline & Xenotime-(Y) & $(\mathrm{Y}, \mathrm{HREE}) \mathrm{PO}_{4}$ & Holer, Østfold, Norway & 13702 \\
\hline & Synthetic $\mathrm{YPO}_{4}$ & $\mathrm{YPO}_{4}(\mathrm{Nd}$ doped $)$ & ORNL, USA & $\mathrm{YPO}_{4}-\mathrm{Nd}$ \\
\hline & Synthetic $\mathrm{NdPO}_{4}$ & $\mathrm{NdPO}_{4}$ (Y doped) & University of St Andrews, UK & $\mathrm{AMB} / 17 / \mathrm{NdPO}_{4}-\mathrm{Y}$ \\
\hline & Vitusite-(Ce) & $\mathrm{Na}_{3}(\mathrm{Ce}, \mathrm{La}, \mathrm{Nd})\left(\mathrm{PO}_{4}\right)_{2}$ & Ilímaussaq, Greenland & $\mathrm{HF} / \mathrm{B} 32 / \mathrm{Vit}$ \\
\hline \multirow[t]{2}{*}{ Fluorcarbonate } & Bastnäsite-(Ce) & $(\mathrm{Ce}, \mathrm{La}) \mathrm{CO}_{3} \mathrm{~F}$ & Itorendrika-Ifasina, Madagascar & G.1963.3.42.1 \\
\hline & Parisite-(Ce) & $\mathrm{Ca}(\mathrm{Ce}, \mathrm{La})_{2}\left(\mathrm{CO}_{3}\right)_{3} \mathrm{~F}_{2}$ & Muzo Mine, Columbia & G.1930.1.1 \\
\hline \multirow[t]{2}{*}{ Solutions } & $\mathrm{Y}^{3+}$ (aqueous) & $\mathrm{Y}^{3+}(\mathrm{aq})\left(1000 \mathrm{mg} / \mathrm{l}\right.$ in $\left.2 \% \mathrm{HNO}_{3}\right)$ & Inorganic Ventures & CGY1 \\
\hline & $\mathrm{Nd}^{3+}$ (aqueous) & $\mathrm{Nd}^{3+}(\mathrm{aq})\left(1000 \mathrm{mg} / \mathrm{l}\right.$ in $\left.2 \% \mathrm{HNO}_{3}\right)$ & Inorganic Ventures & CGNd1 \\
\hline Oxide & Yttrium oxide & $\mathrm{Y}_{2} \mathrm{O}_{3}$ & Beamline in-house standard & $\mathrm{Y}_{2} \mathrm{O}_{3}$ \\
\hline \multirow[t]{2}{*}{ Metal } & Yttrium & $\mathrm{Y}$ & Beamline in-house standard & Y-foil \\
\hline & Neodymium & $\mathrm{Nd}$ & Beamline in-house standard & Nd-foil \\
\hline
\end{tabular}

Table 3. Nearest neighbour bond distances for sites in eudialyte s.s. (Johnsen and Grice, 1999; sample \#15, Ilimaussaq), used as input parameters for eudialyte Y EXAFS refinements. Refined parameters are shown in Table 5.

\begin{tabular}{|c|c|c|c|c|c|c|c|c|c|c|c|}
\hline \multicolumn{3}{|c|}{ N4 site $(\mathrm{Na})$} & \multicolumn{3}{|c|}{$M 1$ site $(\mathrm{Ca})$} & \multicolumn{3}{|c|}{ M2 site (Fe) } & \multicolumn{3}{|c|}{$Z$ site $(Z r)$} \\
\hline Element & $\mathrm{CN}$ & $R(\AA)$ & Element & $\mathrm{CN}$ & $R(\AA ̊)$ & Element & $\mathrm{CN}$ & $R(\AA ̊)$ & Element & $\mathrm{CN}$ & $R(\AA)$ \\
\hline 0 & 8 & $2.53-2.87$ & $\mathrm{O}_{1 \mathrm{a}}$ & 2 & 2.31 & $\mathrm{O}_{1}$ & 4 & 2.04 & $\mathrm{O}_{1 \mathrm{a}}$ & 4 & 2.06 \\
\hline $\mathrm{Cl}$ & 1 & 2.81 & $\mathrm{O}_{1 \mathrm{~b}}$ & 4 & 2.37 & $\mathrm{O}_{2}$ & 2 & 2.75 & $\mathrm{O}_{1 \mathrm{~b}}$ & 2 & 2.07 \\
\hline $\mathrm{Si}$ & 2 & 3.20 & $\mathrm{Fe} / \mathrm{Mn}$ & 1 & 3.42 & $\mathrm{Si}$ & 4 & 3.27 & $\mathrm{Si}$ & 2 & 3.47 \\
\hline $\mathrm{Ca}$ & 4 & 3.42 & $\mathrm{Na}$ & 2 & 3.42 & $\mathrm{Ca}$ & 2 & 3.42 & $\mathrm{Si}$ & 4 & 3.54 \\
\hline $\mathrm{Fe} / \mathrm{Mn}$ & 2 & 3.52 & $\mathrm{O}_{2 \mathrm{a}}$ & 2 & 3.42 & 0 & 2 & 3.45 & $\mathrm{Na}$ & 4 & 3.56 \\
\hline \multirow[t]{3}{*}{$\mathrm{Cl}$} & 1 & 3.54 & $\mathrm{Si}$ & 6 & 3.47 & $\mathrm{Cl}$ & 2 & 3.60 & $\mathrm{Na}$ & 4 & 3.63 \\
\hline & & & $\mathrm{O}_{2 \mathrm{~b}}$ & 2 & 3.58 & & & & $\mathrm{Na}$ & 2 & 3.82 \\
\hline & & & $\mathrm{Ca}$ & 2 & 3.70 & & & & 0 & 2 & 3.89 \\
\hline
\end{tabular}

Table 4. EXAFS refinement results for selected standards.

\begin{tabular}{|c|c|c|c|c|c|c|c|c|c|}
\hline Sample & Path & $\mathrm{CN}$ & $R(\AA)$ & $\sigma^{2}\left(\AA^{-2}\right)$ & $\Delta E_{0}(\mathrm{eV})$ & $S_{0}^{2}$ & $\chi^{2}$ & $R^{a}$ & Reference $^{b}$ \\
\hline Y-foil & $Y-Y$ & 12 & $3.59(1)$ & $0.011(2)$ & $4.6(9)$ & $0.7(1)$ & 3774 & 0.015 & Wyckoff et al. (1964) \\
\hline Y-aqueous & $\mathrm{Y}-\mathrm{O}$ & $8.3(4)$ & $2.38(0.5)$ & $0.005(2)$ & -2 & 1 & 506 & 0.009 & \\
\hline \multirow[t]{3}{*}{$\mathrm{Y}_{2} \mathrm{O}_{3}$} & $\mathrm{Y}-\mathrm{O}$ & $6.2(5)$ & $2.27(1)$ & 0.005 & -6.4 & 1 & 1994 & 0.035 & Santos et al. (2005) \\
\hline & $Y-Y_{1}$ & $6.1(6)$ & $3.53(1)$ & 0.003 & & & & & \\
\hline & $Y-Y_{2}$ & $6.1(6)$ & $4.01(1)$ & 0.004 & & & & & \\
\hline \multirow[t]{7}{*}{$\mathrm{YPO}_{4}-\mathrm{Nd}$} & $\mathrm{Y}-\mathrm{O}_{1 \mathrm{a}}$ & 4 & $2.33(1)$ & 0.004 & $2.4(11)$ & $1.2(1)$ & 995 & 0.047 & Ni et al. (1995) \\
\hline & $\mathrm{Y}-\mathrm{O}_{1 \mathrm{~b}}$ & 4 & $2.40(1)$ & 0.004 & & & & & \\
\hline & $\mathrm{Y}-\mathrm{P}$ & 2 & $3.04(1)$ & 0.007 & & & & & \\
\hline & $Y-Y$ & 4 & $3.79(1)$ & 0.007 & & & & & \\
\hline & $\mathrm{Y}-\mathrm{O}_{1-} \mathrm{O}_{2}$ & 16 & $3.87(1)$ & 0.009 & & & & & \\
\hline & $\mathrm{Y}-\mathrm{O}_{2 \mathrm{a}}$ & 4 & $4.19(2)$ & 0.007 & & & & & \\
\hline & $\mathrm{Y}-\mathrm{O}_{2 b}$ & 8 & $4.26(2)$ & 0.007 & & & & & \\
\hline
\end{tabular}

\footnotetext{
${ }^{\mathrm{a}}$ Final refinements over $k$-range 2.5 to $9 \AA^{-1}, R$ range variable (see text); ${ }^{\mathrm{b}}$ references for the structures used in $F E F F 6$ calculations.
} 
(a)
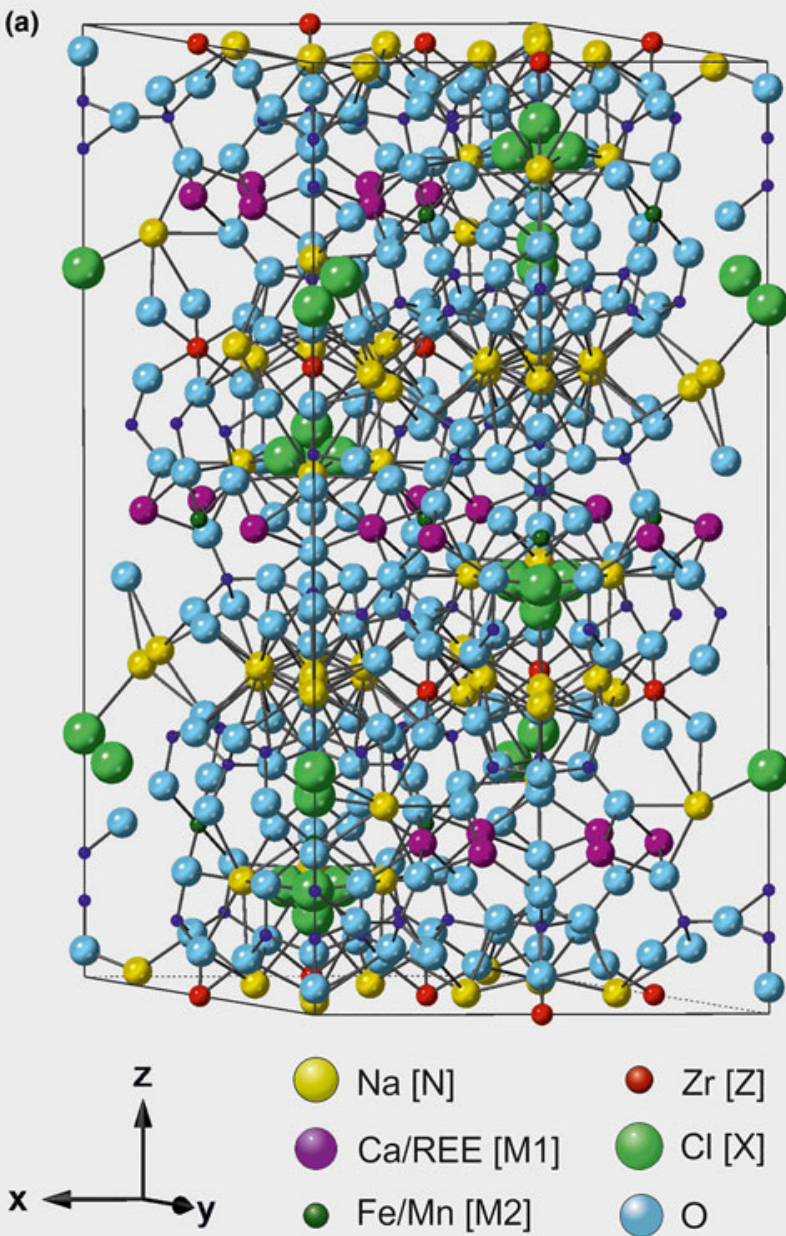

$\mathrm{Na}[\mathrm{N}]$

- Ca/REE [M1]

- Fe/Mn [M2]

- $\mathrm{Si} / \mathrm{Nb}[\mathrm{M} 3 / \mathrm{M} 4 / \mathrm{Si}]$ (b)
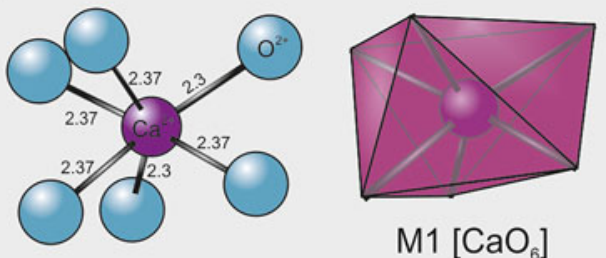

$\mathrm{M} 1\left[\mathrm{CaO}_{6}\right]$

(c)
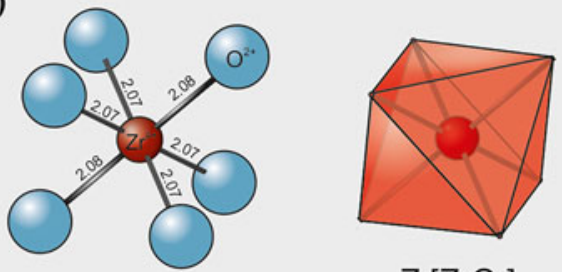

$\mathrm{Z}\left[\mathrm{ZrO}_{6}\right]$

(d)
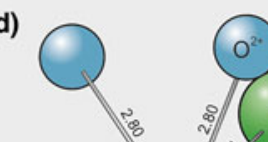
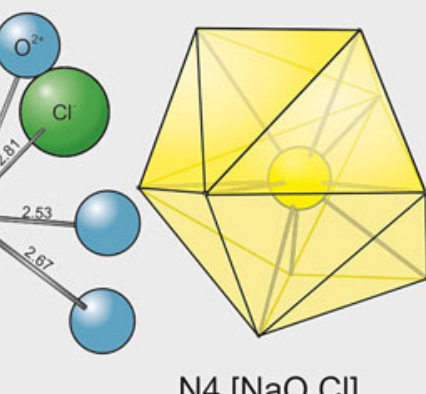

$\mathrm{N} 4\left[\mathrm{NaO}_{8} \mathrm{Cl}\right]$

Fig. 1. (a) Unit-cell crystal structure of Ilímaussaq eudialyte s.s. (from Johnsen and Grice, 1999) and site geometries for: (b) the octahedral Ca-occupied M1 site; (c) the high symmetry octahedral $Z$ site; and $(d)$ the low symmetry $N 4$ site. Nearest and next-nearest neighbour bond distances per site are listed in Table 3.

and narrower absorption peaks than the XANES of minerals in which REE are inferred to occupy lower symmetry sites.

As for the standards, the eudialyte spectra show a sharp and narrow white line at the $\mathrm{Nd} L_{3}$-edge $(6213 \mathrm{eV})$ and small $\mathrm{Ce}$ $L_{2}$-edge absorption peaks in the pre-edge region. Two characteristic features are marked in the eudialyte Nd XANES, labelled B and $C$ (Fig $3 b$ ). Minor variations in the position and relative height of these features, as well as variations in the relative height of the $\mathrm{Ce}^{3+} L_{2}$-edge peak (at $6168 \mathrm{eV}$ ) compared to the $\mathrm{Nd}^{3+} L_{3}$-edge peak $(6215 \mathrm{eV})$, reflect variable $R E E$ concentrations in eudialyte between samples and localities (eudialyte compositions in Table S2). Absorption features for $\mathrm{Ce}^{4+}$ (c. $6179 \mathrm{eV}$ ) are generally absent in eudialyte, although a slight contribution of $\mathrm{Ce}^{4+}$ may be recognised in eudialyte of Norra Kärr.

\section{$Y$ K-edge EXAFS}

The $k^{2}$-weighted EXAFS oscillations as a function of wavenumber $(k$-space) are demonstrated in Fig. 4 along with phase-shifted Fourier-transform functions for a selection of $\mathrm{Y}$ standards and the eudialyte samples. The EXAFS oscillations for all eudialyte samples are near-identical (black lines, Fig. 4c), suggesting an identical structural state for $\mathrm{Y}$ in the studied specimens. Accompanying Fourier-Transform functions (Fig 4d) demonstrate two distinct coordination spheres (shells) at a radial distance of $\sim 2.3 \AA$ and $\sim 3.5 \AA$, suggesting the presence of scattering atoms at those distances and corresponding well to the structural model for the $M 1$ site (Table 3). Also shown in Fig. 4 are best-fit results for the standards and samples (fits provided in Table S5), and refined parameters from which the fits are derived listed in Table 4 . The refinement results are discussed further in the following sections.

\section{Discussion}

XANES

Normalised Y K-edge XANES for eudialyte and standards are shown and annotated in Fig. 2. The standards were selected to demonstrate a range of REE coordination states and point symmetries, such that potential variations in XANES features could 

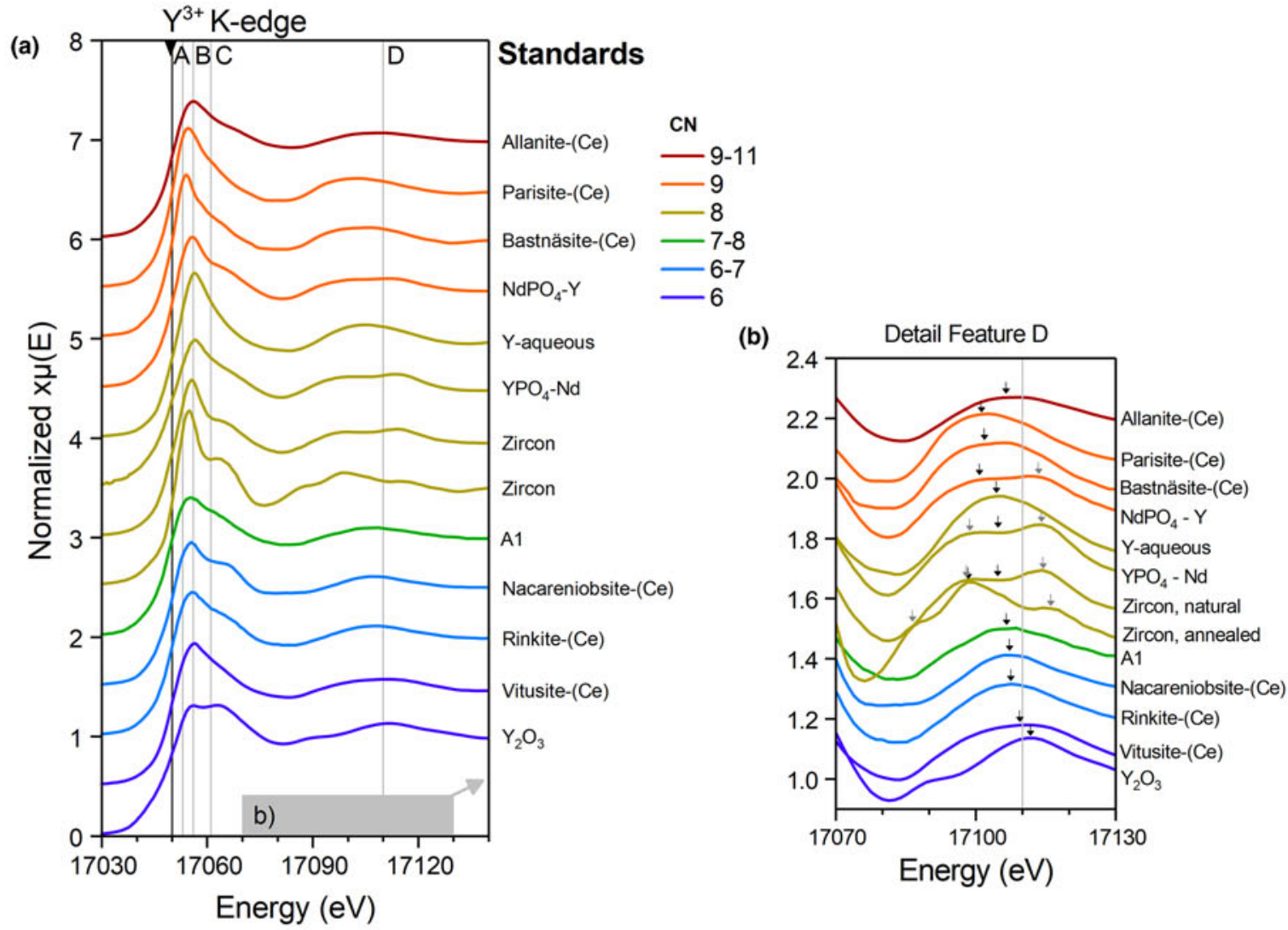

(c)

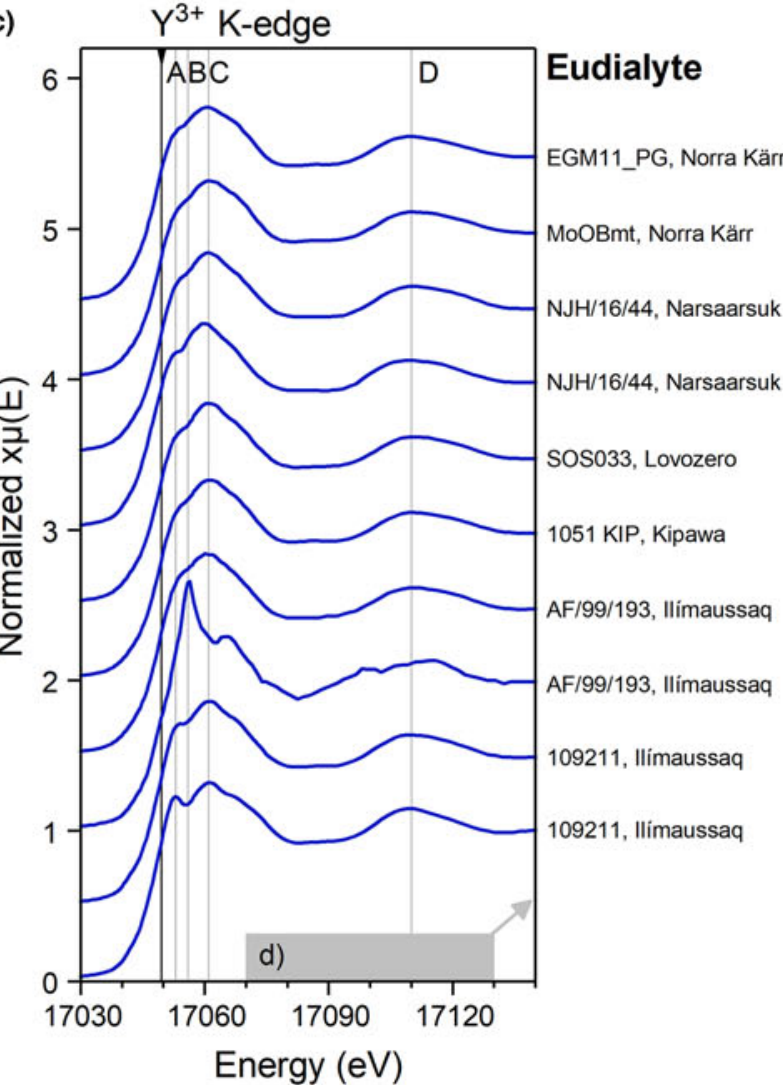

(d)

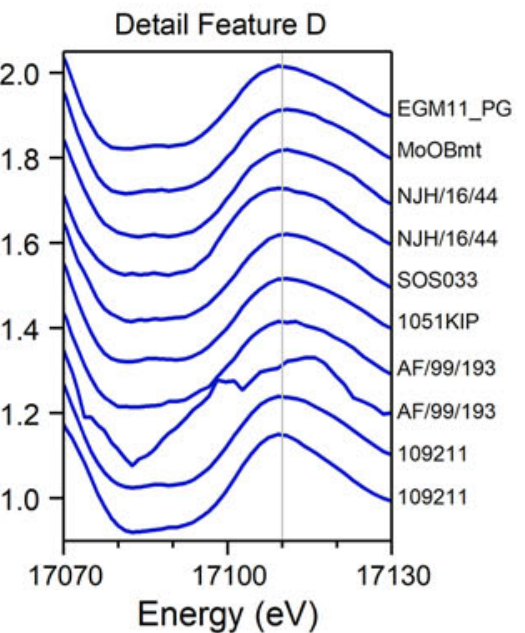

Fig. 2. Yttrium K-edge XANES spectra for ( $a$ ) selected standards and (c) eudialyte. Black line indicates main Y K-edge energy (17,050 eV). 109211 was measured in thin section, other samples as powders. Grey lines labelled A $(17,053 \mathrm{eV}), \mathrm{B}(17,056 \mathrm{eV}), \mathrm{C}(17,061 \mathrm{eV})$ and $\mathrm{D}(17,110 \mathrm{eV})$ mark characteristic features in the eudialyte spectra. Details of feature $\mathrm{D}(b$ and $d$ ) reveal shifts in peak shape and position with increasing REE coordination numbers (CN) for the standards $(b)$, and stronger XANES features for minerals where HREE are inferred to occupy higher symmetry sites $\left(\mathrm{Y}_{2} \mathrm{O}_{3}\right.$, zircon, and $R E E$ phosphates). The peak position of feature $\mathrm{D}$ (grey line) for eudialyte is most comparable to standards where $Y$ is inferred to occupy octahedral sites $(\mathrm{CN}=6)$. 
(a)
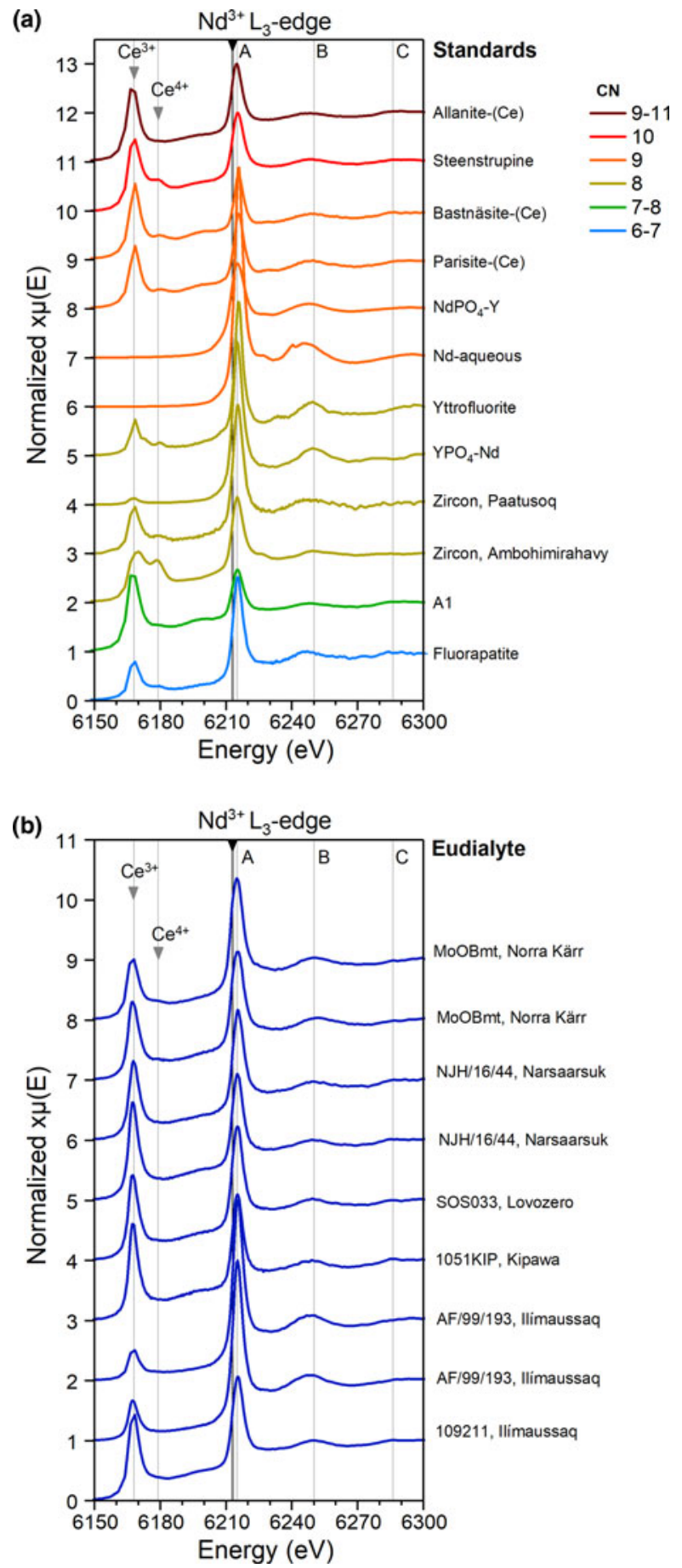

Fig. 3. Neodymium $L_{3}$-edge XANES spectra for $(a)$ eudialyte and $(b)$ selected standards. Cerium $L_{2}$-edges are visible in the pre-edge region for $\mathrm{Nd}$ (at $6168 \mathrm{eV}$ for $\mathrm{Ce}^{3+}$ and $6179 \mathrm{eV}$ for $\left.\mathrm{Ce}^{4+}\right)$. The black line indicates the main $\mathrm{Nd}^{L_{3}}$-edge at $6213 \mathrm{eV}$. Grey vertical lines labelled A $(6215 \mathrm{eV}), \mathrm{B}(6250 \mathrm{eV})$ and C $(6286 \mathrm{eV})$ mark the main features in the eudialyte spectra. Differences in relative heights of absorption edges reflect natural variations in $\mathrm{Ce}^{3+} / \mathrm{Ce}^{4+}$ and $\mathrm{Ce} / \mathrm{Nd}$ ratios in the analysed minerals. Note the absence of $\mathrm{Ce}$ absorption in the synthetic phases and $\mathrm{Nd}$ in aqueous solution.

be analysed qualitatively. Although limited Y K-edge XANES data are available in the literature, measured spectra for standards $\mathrm{Y}_{2} \mathrm{O}_{3}, \mathrm{Y}_{\text {aqueous }}^{3+}$ and $\mathrm{YPO}_{4}$ compare well to published spectra (Dura et al., 2013; Tanaka et al., 2008, 2009). The standards and samples demonstrate variable absorption features, labelled
A to D in Fig 2. Overall, phases in which REE are inferred to occupy higher point symmetry sites show more pronounced absorption features. We infer that sites with higher point symmetry favour the multiple resonances that generate XANES with more detailed fine structure, whereas low point symmetry sites give rise to broader XANES features. Another observation is the apparent shift of c. $10 \mathrm{eV}$ in the position of feature $\mathrm{D}$ with changing coordination states (Fig $2 b$ ). The position of the peak at feature D for the EGM samples lies at $17,110 \mathrm{eV}$ and is most comparable to the spectra for standards in which $\mathrm{Y}$ are inferred to occupy 6-coordinated sites (Fig. $2 b, d$ ). From this we tentatively infer that $\mathrm{Y}$ in EGM is 6-coordinated. However, none of the 6-coordinated standards display the characteristic doublepeaked and broadened absorption edge observed for eudialyte (i.e. feature $\mathrm{A}$ at $17,053 \mathrm{eV}$ and $\mathrm{C}$ at 17,061 eV). Hence, within our limited XANES dataset for Y-bearing minerals, the eudialyte XANES spectra are unique. If we disregard the anomalous spectrum for AF/99/193, which was collected using a small $(3 \mu \mathrm{m} \times$ $3 \mu \mathrm{m})$ beam at I18, the consistency in the other eudialyte XANES spectra suggests that $\mathrm{Y}$ occupies the same structural state in all measured samples. We interpret the anomalous spectrum as the illumination of an inclusion or an alteration product within the crushed sample. This particular spectrum shows a characteristic shoulder at $17,065 \mathrm{eV}$ and additional features at 17,099 and $17,115 \mathrm{eV}$, corresponding closely to the XANES features of zircon (Fig 2a). This may suggest the presence of 8 -coordinated $\mathrm{Y}$ in microscopic zircon as an alteration product of eudialyte (van de Ven et al., 2019).

The $\mathrm{Nd} L_{3}$-XANES show narrow white lines that are characteristic for $L$-edge absorption spectra (de Groot, 1995). Unlike the $\mathrm{Y} K$-XANES, there is no systematic change with increasing coordination number in the $\mathrm{Nd} L_{3}$-XANES (Fig $3 b$ ). Variations in the height of the pre-edge absorption features demonstrate natural variations in $\mathrm{Ce}^{3+} / \mathrm{Ce}^{4+}$ and $\mathrm{Ce} / \mathrm{Nd}$ ratios. Our reference sample from the most oxidised environment is a hydrothermally altered zircon derived from a lateritic weathering profile on peralkaline rocks of the Ambohimirahavavy complex, Madagascar (Estrade et al., 2014), which accordingly shows a stronger $\mathrm{Ce}^{4+}$ absorption feature at $6179 \mathrm{eV}$. Similar to the Y XANES, standards with higher point symmetries ('yttrofluorite', xenotime $\left(\mathrm{YPO}_{4}\right.$ $\mathrm{Nd}$ ), Nd-aqueous) show more pronounced Nd XANES features and narrower absorption peaks. The Nd XANES for zircon appears to be an exception to this rule, suggesting that a proportion of the larger $L R E E^{3+}$, in contrast to $H R E E^{3+}$, do not substitute on the high symmetry 8 -fold Zr-site but on low symmetry interstitial sites (Friis et al., 2010), metamict parts of the structure, or a combination of the two. The XANES spectra for $\mathrm{Nd}$ in aqueous solution (weak nitric acid) exhibit a particularly strong white line and additional features that are not observed in the other absorption spectra. From this we infer that $\mathrm{Nd}$ in aqueous solution occurs as highly ordered and symmetric $\mathrm{Nd}-\mathrm{OH}$ complexes.

Overall, Nd XANES for eudialyte are similar to the XANES for those $R E E$-standards in which the REE occupy low-symmetry sites, but with different coordination numbers from the inferred REE sites in eudialyte, in particular steenstrupine, A1, fluorapatite and allanite-(Ce), parisite-(Ce) and bastnäsite-(Ce). As such, the $\mathrm{Nd} L_{3}$-edge appears to be insensitive to coordination number but rather reflects the point symmetry of the site. However, we infer that $\mathrm{Nd}$, along with the other light $R E E$, occupy both the 6-fold $M 1$ site and the low symmetry 9-coordinated N4 site. 

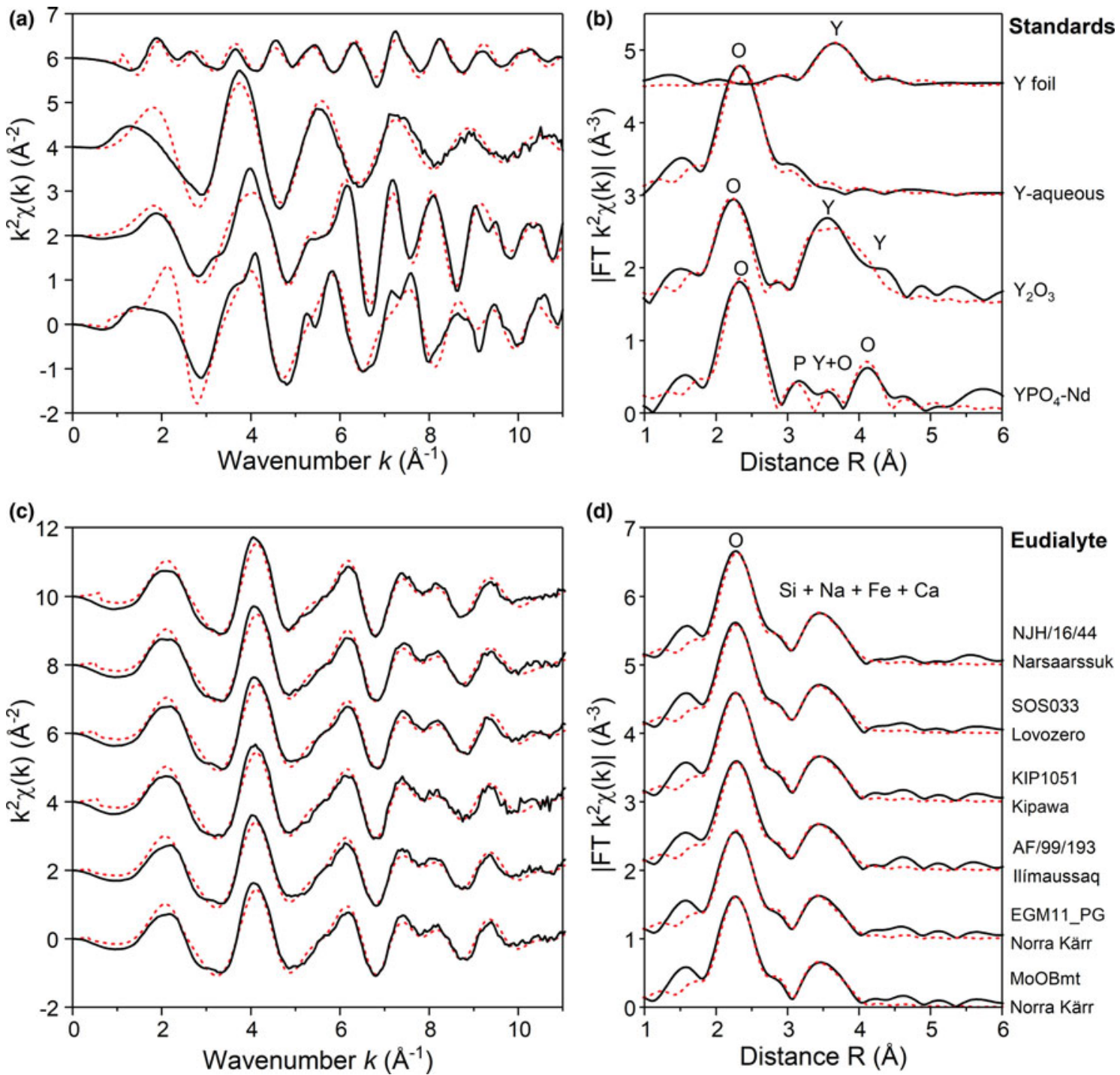

Fig. 4. $K^{2}$-weighted $Y K$-edge EXAFS oscillations and corresponding phase-shifted Fourier transforms (FT) for $(a, b)$ selected $Y$ standards and $(c, d)$ eudialyte samples. Black lines represent experimental data, and the red dashed lines are least-square fits obtained in Artemis. Fitting parameters are given in Table 4 (standards) and Table 5 (eudialyte). Note the identical EXAFS patterns for eudialyte samples of different provenance.

\section{EXAFS refinements}

\section{Standards}

Prior to modelling the Y K-EXAFS data to the complex structural models for eudialyte, we first fitted EXAFS spectra for selected $Y$ standards ( $\mathrm{Y}$ foil, $\mathrm{Y}$ oxide, $\mathrm{YPO}_{4}$ and $\mathrm{Y}$ in solution) to test the accuracy of our refinement procedures in Artemis.

The EXAFS spectrum for $\mathrm{Y}_{2} \mathrm{O}_{3}$ compares well to those reported by Lazdins and Kuzmin (2015) and Tanaka et al. (2008) and is fitted to the cubic- $\mathrm{Y}_{2} \mathrm{O}_{3}$ structure from Santos et al. (2005), comprising three single-scattering paths of $6 \mathrm{O}$ at $2.28 \AA, 6 \mathrm{Y}$ at $3.51 \AA$ and $6 \mathrm{Y}$ at $4 \AA$. When fixing the coordination numbers, fitted bond distances for the single-scattering paths are $2.271,3.53$ and $4.01( \pm 0.01) \AA$, respectively ( $R$ factor $=0.035$, Table 4$)$. These are consistent with the structural model and within error of EXAFS parameters obtained by Tanaka et al. (2008).

Speciation studies of $R E E$ in aqueous solutions at ambient temperatures suggest that the light rare earths $(\mathrm{La}-\mathrm{Eu})$ favour a 9-fold hydration sphere, while the HREE (Gd-Lu, including Y) favour 8-fold hydration (Kanno and Hiraishi, 1984; DíazMoreno et al., 2000; Persson et al., 2008; Tanaka et al., 2008; Finck et al., 2017; Liu et al., 2017), with average rare-earth to oxygen bond distances steadily decreasing for the light to the heavy REE. A single-shell fit for the EXAFS pattern (Fig. $4 a, b$ ) of $\mathrm{Y}^{3+}$ dissolved in weak nitric acid yields a best fit for $8.3 \pm 0.4$ oxygens (of surrounding water molecules) at $2.380 \pm 0.005 \AA\left(\sigma^{2}=0.011 \pm\right.$ $0.002 \AA^{-2}, R$ factor $=0.009$, Table 4 ). These distances are longer than those reported for aqueous $\mathrm{Y}^{3+}$ in previous EXAFS studies $(2.354 \pm 0.005 \AA$, Tanaka et al. (2008) and $2.353 \pm 0.001 \AA$, Díaz-Moreno et al. (2000). However, the coordination number is consistent with the literature indicating $\mathrm{Y}$ in solution predominantly occurs in an 8-fold hydration sphere. The solutions studied by other authors were mostly neutral whereas our solution was acidic $\left(0.3 \mathrm{M} \mathrm{HNO}_{3}, \mathrm{pH}=0.5\right)$ and we infer that protonation of the $\mathrm{Nd}$ complex has modified the bond distance.

The coordination sphere around $\mathrm{Y}$ in xenotime is 8-fold, similar to the coordination of $R E E$ in zircon. Four individual 
coordination shells are visible of the Fourier-transform function (Fig. 4b), corresponding to surrounding $\mathrm{O}, \mathrm{P}$ and $\mathrm{Y}$ atoms within the $4.3 \AA$ range. The spectrum was fitted to a structural model of $\mathrm{YPO}_{4}$ from Ni et al. (1995) over an adjusted $k$ range of $2.5-10 \AA^{-1}$ and $R$ range of 1.25-4.2 $\AA$ to include all shells observed in the Fourier transform, yielding bond distances consistent with the model for all relevant scattering paths ( $R$ factor 0.047 , Table 4 ).

The Fourier transform for the metallic $Y$ foil reveals a single coordination shell around $3.6 \AA$, and an EXAFS signal that is somewhat attenuated (Fig. 4a,b). The coordination sphere of $\mathrm{Y}$ in metallic form is 12 -fold, comprising $6 \mathrm{Y}$ atoms at $3.56 \AA$ and $6 \mathrm{Y}$ at $3.65 \AA$ in a hexagonal close-packed structure (Wyckoff, 1964). The spectrum is successfully fitted to the model with 12 $\mathrm{Y}$ (fixed $\mathrm{CN})$ at an average distance of $3.59 \pm 0.01 \AA\left(\sigma^{2}=\right.$ $0.011 \AA^{-2}, R$ factor $=0.015, k$ range $=2.5-9 \AA^{-1}$, and $R$ range $=$ 2.5-4 $\AA$ ), while floating the amplitude reduction factor to account for the attenuated signal (Table 4). More refinement details for this standard are described in Supplementary 1.

\section{Eudialyte-group minerals}

To determine the coordination sphere of $\mathrm{Y}$ in the structure of EGM, EXAFS spectra for each sample were fitted to structural models of the $M 1, N$ and $Z$ sites as discussed in the introduction. Fitting was done in a step-wise manner by sequentially including more scattering paths (increasing the $R$ range), while minimising the number of variables per fit to ensure a determinacy of $>2$. In the first step of the refinement, yttrium-oxygen bond distances, Debye-Waller factors and $\Delta E_{0}$ were fitted for the first shell only, using a fixed amplitude reduction factor $\left(S_{0}^{2}=1\right)$ and a reduced $R$ range of $1-2.5 \AA\left(k\right.$ range $\left.=2.5-10 \AA^{-1}\right)$. For the distorted octahedral $M 1$ site, we provided a structural model with two oxygen paths, one to model the two shorter bonds $\left(\mathrm{Y}-\mathrm{O}_{1 \mathrm{a}}\right)$ and one to model the four longer bonds $\left(\mathrm{Y}-\mathrm{O}_{2 \mathrm{~b}}\right.$ ) (Fig 1, Table 3). The first shell fits yield robust $\mathrm{Y}-\mathrm{O}$ distances of 2.23 $\pm 0.01 \AA$ and $2.30 \pm 0.01 \AA$ for the short and long $\mathrm{Y}-\mathrm{O}$ paths, respectively ( $R$ factors of $0.010-0.016$ ), indicating on average $3 \%$ shortening of the $M 1$ cation-oxygen bond distances when $\mathrm{Ca}$ is replaced by $\mathrm{Y}$.

In the second step, we extended the $R$ range to $1-4 \AA$ to include the second peak visible in the Fourier-transform function (Fig. $4 d$ ). The broad shape of this peak suggests the presence of next-nearest neighbour atoms at distances between 3.4 and 3.6 A, consistent with the expected cluster of next-nearest neighbours for the $\mathrm{M} 1$ site (Fe, $\mathrm{Ca}, \mathrm{Na}, \mathrm{O}$ and $\mathrm{Si}$; Table 3 ). Refinement of the scattering paths in this second shell is challenging due the variety of elements present at this radial distance to the $M 1$ site (see Fig. 6, below), and hence the high number of variables required in the fitting procedure. However, an attempt was made to fit all relevant scattering paths within $3.7 \AA$ distance of the absorbing $\mathrm{Y}$ atom. Over the fitted $k$ - and $R$-range of $2.5-10 \AA^{-1}$ and $1-4 \AA$, respectively, the number of independent variables $(N)$ supported by the fit is 14.11 . To ensure a determinacy above $2(\mathrm{~N} / \mathrm{P}), 7$ parameters $(P)$ could be fitted in the procedure. We reduced the number of fitted variables to $<7$ by fixing $\Delta E_{0}$ to the value obtained from the first shell fit, and by using the same $\sigma^{2}$ and $\Delta R$ for all oxygen paths. Fit parameters for $\sigma^{2}$ and $\Delta R$ for the other paths were iteratively evaluated and amalgamated when giving similar values or high correlation factors between parameters.

The final two-shell fits yield $R$ factors between 0.015 and 0.021 (Table 5). Results are shown in Fig. $4 c$ and $d$. Isolated contributions for each scattering path are shown in Fig. 5 to illustrate the most important scatterers in the second coordination sphere;
Table 5. Yttrium EXAFS refinements for the eudialyte-group minerals studied.

\begin{tabular}{|c|c|c|c|c|c|c|c|c|}
\hline Sample & Path & $\mathrm{CN}$ & $R(\AA)$ & $\sigma^{2}\left(\AA^{-2}\right)$ & $\Delta \mathrm{E}_{0}(\mathrm{eV})$ & $\mathrm{S}_{0}^{2}$ & $\chi^{2}$ & $R^{\mathrm{a}}$ \\
\hline NJH/16/44 & $\mathrm{Y}-\mathrm{O}_{1 \mathrm{a}}$ & 2 & $2.24(1)$ & $0.003(1)$ & 1.5 & 1 & 179 & 0.015 \\
\hline \multirow[t]{7}{*}{ Narsaarsuk } & $\mathrm{Y}-\mathrm{O}_{1 \mathrm{~b}}$ & 4 & $2.30(1)$ & $0.003(1)$ & & & & \\
\hline & $\mathrm{Y}-\mathrm{O}_{2 \mathrm{a}}$ & 2 & $3.34(1)$ & $0.003(1)$ & & & & \\
\hline & $\mathrm{Y}-\mathrm{Fe}$ & 1 & $3.3(2)$ & $0.01(4)$ & & & & \\
\hline & $\mathrm{Y}-\mathrm{Na}$ & 2 & $3.48(3)$ & $0.005(6)$ & & & & \\
\hline & $\mathrm{Y}-\mathrm{Si}$ & 6 & $3.50(3)$ & $0.005(6)$ & & & & \\
\hline & $\mathrm{Y}-\mathrm{O}_{2 \mathrm{~b}}$ & 2 & $3.53(1)$ & $0.003(1)$ & & & & \\
\hline & $\mathrm{Y}-\mathrm{Ca}$ & 2 & $3.82(5)$ & $0.006(5)$ & & & & \\
\hline SOS033 & $\mathrm{Y}-\mathrm{O}_{1 \mathrm{a}}$ & 2 & $2.23(1)$ & $0.004(1)$ & 1.1 & 1 & 181 & 0.018 \\
\hline \multirow[t]{7}{*}{ Lovozero } & $\mathrm{Y}-\mathrm{O}_{1 \mathrm{~b}}$ & 4 & $2.29(1)$ & $0.004(1)$ & & & & \\
\hline & $\mathrm{Y}-\mathrm{Fe}$ & 1 & $3.29(7)$ & $0.008(8)$ & & & & \\
\hline & $\mathrm{Y}-\mathrm{O}_{2 \mathrm{a}}$ & 2 & $3.34(1)$ & $0.004(1)$ & & & & \\
\hline & $\mathrm{Y}-\mathrm{Na}$ & 2 & $3.43(3)$ & $0.006(8)$ & & & & \\
\hline & $\mathrm{Y}-\mathrm{Si}$ & 6 & $3.49(3)$ & $0.006(8)$ & & & & \\
\hline & $\mathrm{Y}-\mathrm{O}_{2 b}$ & 2 & $3.52(1)$ & $0.004(1)$ & & & & \\
\hline & $\mathrm{Y}-\mathrm{Ca}$ & 2 & $3.80(4)$ & $0.005(4)$ & & & & \\
\hline $1051 \mathrm{KIP}$ & $\mathrm{Y}-\mathrm{O}_{1 \mathrm{a}}$ & 2 & $2.23(1)$ & $0.004(1)$ & 1.1 & 1 & 498 & 0.020 \\
\hline \multirow[t]{7}{*}{ Kipawa } & $\mathrm{Y}-\mathrm{O}_{1 \mathrm{~b}}$ & 4 & $2.29(1)$ & $0.004(1)$ & & & & \\
\hline & $\mathrm{Y}-\mathrm{O}_{2 \mathrm{a}}$ & 2 & $3.34(1)$ & $0.004(1)$ & & & & \\
\hline & $\mathrm{Y}-\mathrm{Na}$ & 2 & $3.4(2)$ & $0.01(2)$ & & & & \\
\hline & $\mathrm{Y}-\mathrm{Fe} / \mathrm{Mn}$ & 1 & $3.4(2)$ & $0.01(2)$ & & & & \\
\hline & $\mathrm{Y}-\mathrm{Si}$ & 6 & $3.48(5)$ & $0.004(5)$ & & & & \\
\hline & $\mathrm{Y}-\mathrm{O}_{2 \mathrm{~b}}$ & 2 & $3.52(1)$ & $0.004(1)$ & & & & \\
\hline & $\mathrm{Y}-\mathrm{Ca}$ & 2 & $3.80(6)$ & $0.007(8)$ & & & & \\
\hline AF/99/193 & $\mathrm{Y}-\mathrm{O}_{1 \mathrm{a}}$ & 2 & $2.24(1)$ & $0.004(1)$ & 1.2 & 1 & 33 & 0.017 \\
\hline \multirow[t]{7}{*}{ Ilímaussaq } & $\mathrm{Y}-\mathrm{O}_{1 \mathrm{~b}}$ & 4 & $2.30(1)$ & $0.004(1)$ & & & & \\
\hline & $\mathrm{Y}-\mathrm{Fe}$ & 1 & $3.29(6)$ & $0.007(6)$ & & & & \\
\hline & $\mathrm{Y}-\mathrm{O}_{2 \mathrm{a}}$ & 2 & $3.35(1)$ & $0.004(1)$ & & & & \\
\hline & $\mathrm{Y}-\mathrm{Na}$ & 2 & $3.43(3)$ & $0.006(4)$ & & & & \\
\hline & $\mathrm{Y}-\mathrm{Si}$ & 6 & $3.50(3)$ & $0.006(4)$ & & & & \\
\hline & $\mathrm{Y}-\mathrm{O}_{2 \mathrm{~b}}$ & 2 & $3.53(1)$ & $0.004(1)$ & & & & \\
\hline & $\mathrm{Y}-\mathrm{Ca}$ & 2 & $3.80(5)$ & $0.008(6)$ & & & & \\
\hline MoOBmt & $\mathrm{Y}-\mathrm{O}_{1 \mathrm{a}}$ & 2 & $2.23(1)$ & $0.003(1)$ & 0 & 1 & 182 & 0.019 \\
\hline \multirow[t]{7}{*}{ Norra Kärr } & $\mathrm{Y}-\mathrm{O}_{1 \mathrm{~b}}$ & 4 & $2.29(1)$ & $0.003(1)$ & & & & \\
\hline & $\mathrm{Y}-\mathrm{O}_{2 \mathrm{a}}$ & 2 & $3.34(1)$ & $0.003(1)$ & & & & \\
\hline & $\mathrm{Y}-\mathrm{Na}$ & 2 & $3.4(2)$ & $0.01(2)$ & & & & \\
\hline & $\mathrm{Y}-\mathrm{Fe}$ & 1 & $3.4(2)$ & $0.01(2)$ & & & & \\
\hline & $\mathrm{Y}-\mathrm{Si}$ & 6 & $3.48(5)$ & $0.005(5)$ & & & & \\
\hline & $\mathrm{Y}-\mathrm{O}_{2 \mathrm{~b}}$ & 2 & $3.52(1)$ & $0.003(1)$ & & & & \\
\hline & $\mathrm{Y}-\mathrm{Ca}$ & 2 & $3.79(5)$ & $0.006(7)$ & & & & \\
\hline EGM11_PG & $\mathrm{Y}-\mathrm{O}_{1 \mathrm{a}}$ & 2 & $2.24(1)$ & $0.004(1)$ & 0.6 & 1 & 144 & 0.021 \\
\hline \multirow[t]{7}{*}{ Norra Kärr } & $\mathrm{Y}-\mathrm{O}_{1 \mathrm{~b}}$ & 4 & $2.30(1)$ & $0.004(1)$ & & & & \\
\hline & $\mathrm{Y}-\mathrm{Fe}$ & 1 & $3.34(7)$ & $0.01(1)$ & & & & \\
\hline & $\mathrm{Y}-\mathrm{O}_{2 \mathrm{a}}$ & 2 & $3.34(1)$ & $0.004(1)$ & & & & \\
\hline & $\mathrm{Y}-\mathrm{Na}$ & 2 & $3.44(3)$ & $0.005(4)$ & & & & \\
\hline & $\mathrm{Y}-\mathrm{Si}$ & 6 & $3.50(3)$ & $0.005(4)$ & & & & \\
\hline & $\mathrm{Y}-\mathrm{O}_{2 \mathrm{~b}}$ & 2 & $3.52(1)$ & $0.004(1)$ & & & & \\
\hline & $\mathrm{Y}-\mathrm{Ca}$ & 2 & $3.80(6)$ & $0.012(9)$ & & & & \\
\hline
\end{tabular}

${ }^{\text {a }}$ Final parameters are fitted over the $k$ range $2.5-10 \AA^{-1}$ and $R$ range $1-4 \AA$

$\mathrm{Si}$ and $\mathrm{Ca}$, respectively, belonging to 6 corner-linked $\left[\mathrm{SiO}_{4}\right]$ tetrahedra and two edge-linked $M 1$ sites (Fig. 6). The other scatterers; $\mathrm{Fe}, \mathrm{Na}$, and $\mathrm{O}$ (part of one edge-linked M2 site, and two sidelinked $\mathrm{N}$-sites, respectively) only make minor contributions to the overall EXAFS signal (Fig. 5). Accordingly, the Fe (or Mn) and $\mathrm{Na}$ path parameters are less well constrained, which is reflected in more variable bond distances, larger Debye-Waller factors and greater uncertainties (Table 5).

Given the complexity of the second coordination sphere, it is important to note that the quality of the refined parameters strongly depend on the structural model used, i.e. the assumed site and type of EGM in question. Because all samples are refined to a structural model for the $M 1$ site in eudialyte s.s., compositional variations and associated changes in geometry and type of second-nearest neighbour scatterers among the analysed samples are unaccounted for. These would influence the type of 


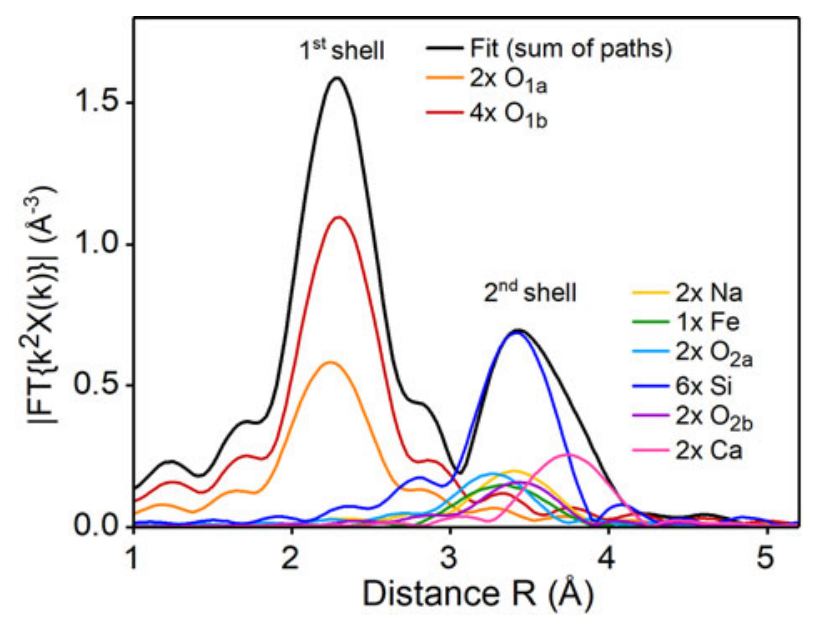

Fig. 5. Radial distribution function (phase-shifted $k^{2}$-weighted Fourier transforms) showing contributions of individual scattering paths to the final fit (black line) for eudialyte $Y$ EXAFS refinements (as shown in Fig $4 c, d$ ) on the $M 1$ site (in eudialyte s.s.). All single-scattering paths within $3.7 \AA$ distance of the central atom in $M 1$ (Table 3, Fig 6) are shown. Contributions of multiple-scattering are negligible and not considered in the refinements.

scatterers present in the second coordination sphere, but not the first shell parameters for the geometry of the REE site. Refinements of the data for $R E E$ using structural models for the $N 4$ and $Z$ sites were unsuccessful.

We can summarise the Y K-edge X-ray absorption data for eudialyte-group minerals as follows: (1) we find an overall consistency in the morphology of the XANES and EXAFS for the measured eudialyte; (2) identified XANES features are most comparable to standards where REE occupy 6-coordinated sites; (3) Y-O bond distances of 2.24-2.3 $\AA$ are consistent with Y substitution for octahedral $\mathrm{Ca}$ on the $M 1$ site; (4) Y substitution on the $M 1$ site results in 3\% shortening of $M 1$ site bond lengths relative to Ca-occupied $M 1$ bond lengths (corresponding to a $9 \%$ volumetric contraction); and (5) the second coordination sphere is successfully modelled with expected next-nearest neighbours ( $\mathrm{Si}, \mathrm{Ca}, \mathrm{Fe}, \mathrm{Na}$ and $\mathrm{O}$ ) up to a radial distance of $3.6 \AA$ around the $M 1$ central atom.

Our results are consistent with Y (and by inference other heavy $R E E$ ) dominantly substituting for $\mathrm{Ca}$ on the $M 1$ site. The local geometry of sites surrounding the Y-occupied $M 1$ site (half a sixmembered ring of edge-shared $M 1$ octahedra) as fitted to the EXAFS data is shown in Fig. 6.

\section{Lattice strain REE partitioning models}

The Y EXAFS refinements indicate that Y-O bond distances are $\sim 0.08 \AA$ (3\%) shorter than average $\mathrm{Ca}-\mathrm{O}$ bond lengths on the M1 site as inferred from XRD refinement. The ionic radius for $\mathrm{Y}^{3+}(0.9 \AA)$ is $\sim 10 \%$ smaller than divalent $\mathrm{Ca}^{2+}(1 \AA)$ in octahedral coordination, and so the $\sim 3 \%$ contraction in bond distances is a non-linear response to the substituent. Most structures accommodate minor and trace substituents by expanding or collapsing around the larger or smaller atom. Some structures (e.g. Ca site in calcite, Finch and Allison, 2007), flex readily, expanding and contracting as elements are placed on the site to provide bond distances that match the sum of ionic radii for the substituent and oxygen. In such cases the local coordination is dictated by the size of the substituent. Conversely, structures may be rigid,

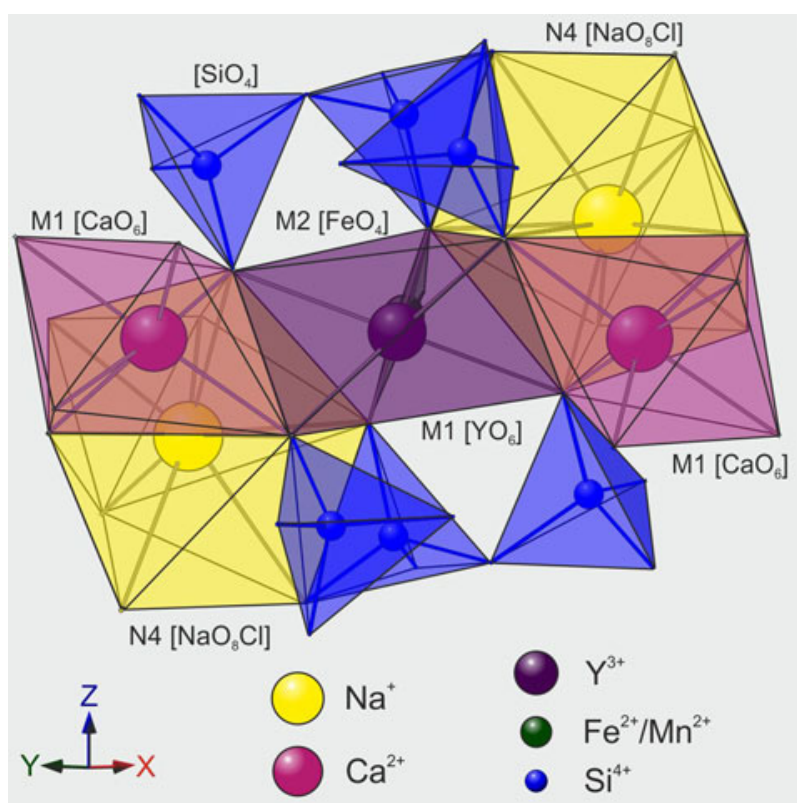

Fig. 6. Local structure for Y-occupied $M$ site showing nearest neighbour polyhedra as probed by EXAFS. Projection along [110] showing half of a six-membered $\mathrm{M}_{6} \mathrm{O}_{36}$-ring. Anions (oxygen and chlorine) are not shown.

where the geometry of the site is fixed and the substituent ion must comply with it. The 'stiffness' of a site is expressed by its Young's modulus ( $E$, in $\mathrm{GPa})$, i.e. rigid sites have large Young's moduli and those with lower values are flexible. Sites that flex readily will more easily accommodate elements of varying ionic radii. This concept is quantitatively expressed by the lattice strain model of Blundy and Wood (1994), which allows the prediction of trace-element partitioning as a function of ionic radius and Young's modulus of the site. In this section we explore the lattice strain model for REE in eudialyte-group minerals in light of the EXAFS results.

Our EXAFS data do not provide evidence for $\mathrm{Y}$ on either the $N, M 2$ or $Z$ sites in the EGM structure, and instead indicate that $\mathrm{Y}$ (and by inference other similarly sized heavy REE) substitutes mainly for $\mathrm{Ca}$ on the octahedral $M 1$ site. Substitution of 9-fold $\mathrm{Y}^{3+}(1.08 \AA)$ for 9 -fold $\mathrm{Na}^{+}(1.24 \AA)$ on the $N$ site may not be anticipated due to substantial differences in size and charge. Yet $\mathrm{XRD}$ refinements commonly infer the presence of light $R E E$, as well as $\mathrm{Sr}, \mathrm{K}, \mathrm{Ca}$ and $\mathrm{H}_{2} \mathrm{O}$ on the $N$ site, suggesting these sites are relatively flexible. Similarly, substitution of 6 -fold $\mathrm{Y}^{3+}$ $(0.9 \AA)$ for 6 -fold $\mathrm{Zr}^{4+}(0.72 \AA)$ would be unlikely without posing considerable strain on the overall structure. Our failure to identify $\mathrm{Y}$ on the $Z$ site suggests that the $Z$ site is indeed too rigid to accommodate larger elements. This hints at substantial contrasts in the Young's moduli of the different sites in the eudialyte structure. Indeed, experimental data for cation-anion polyhedra in silicates and oxides demonstrate a linear increase of Young's moduli of a site with its charge to size ratio (the $Z / d^{3}$ ratio, where $d$ is bond distance; Blundy and Wood, 2003; Hazen and Finger, 1979). On the basis of this relationship we can make a first order estimate of the Young's moduli for sites in the EGM structure by extrapolation from their $Z / d^{3}$ values (Fig. 5 in Blundy and Wood, 2003). Young's moduli estimated in this way for the N4, $M 1, M 2$ and $Z$ sites in eudialyte s.s. occupied by ${ }^{\mathrm{IX}} \mathrm{Na}^{+}{ }^{\mathrm{VI}} \mathrm{Ca}^{2+}$, ${ }^{\mathrm{IV}} \mathrm{Fe}^{2+}$ and ${ }^{\mathrm{VI}} \mathrm{Zr}^{4+}$, respectively, are $80,200,600$ and $3000 \mathrm{GPa}$ (Table 6). 
Table 6. Site parameters and estimated Youngs moduli for lattice strain calculations.

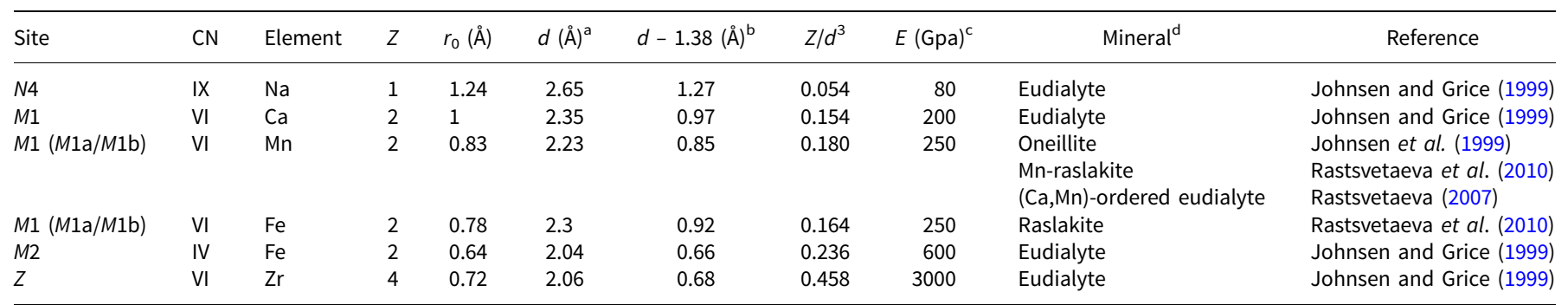

${ }^{a}$ Mean bond distance from crystallographic data; ${ }^{b}$ ideal size of site $r_{0}$ based on crystallographic bond distance minus the ionic radius of oxygen (1.38); ${ }^{C}$ Young's Modulus ( $E$ ) estimated from charge to size relations $\left(z / d^{3}\right)$ in Blundy and Wood (2003); ${ }^{d}$ reference for the crystallographic data.

Using the lattice strain equation (Blundy and Wood, 1994, modified after Brice, 1975) we can calculate relative partition coefficients for a series of isovalent elements on a site ' $\mathrm{M}$ ', as a function of ionic radii $\left(r_{i}\right)$ :

$$
\frac{D_{i}}{D_{0(M)}^{n+}}=\exp \left\{\frac{-4 \pi \mathrm{N}_{\mathrm{A}} E_{M}^{n+}\left[\frac{1}{2} r_{0}^{n+}\left(r_{i}-r_{0(M)}^{n+}\right)^{2}+\frac{1}{3}\left(r_{i}-r_{0(M)}^{n+}\right)^{3}\right]}{\mathrm{R} T}\right\}
$$

where $\mathrm{N}_{\mathrm{A}}$ is the Avogadro's number, $\mathrm{R}$ the gas constant, $T$ is temperature in Kelvin, $r_{0(M)}^{n+}$ the zero strain radius of site $M$ and $E_{M}^{n+}$ its Young's modulus. As the difference in radius between the substituent and the site increases, relative partition coefficients decrease parabolically from a maximum value of 1 at $r_{0(M)}^{n+}$. The tightness of the parabola (Onuma curve) relates to the Young's modulus, i.e. $E_{M}^{n+}$ (Fig. 7). Note that equation 1 is rewritten to provide relative partition coefficients $\left(\frac{D_{i}}{D_{0(M)}^{+}}\right)$, rather than absolute partition coefficients $\left(D_{i}\right)$. This is because no absolute mineral-melt partitioning data are available for the eudialyte-group minerals, and hence $D_{0(M)}^{n+}$ is unconstrained. This absence of data is largely a consequence of poorly

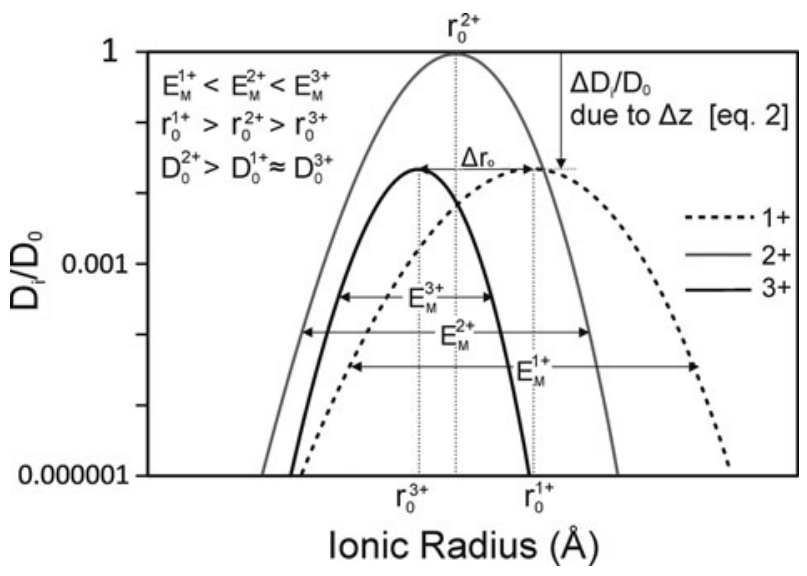

Fig. 7. Schematic Onuma curves plotting relative partition coefficients $\left(D_{\mathrm{i}} / D_{0}\right)$ against ionic radii for series of uni-, di- and trivalent cations onto site $\mathrm{M}^{2+}$. The width of the parabola reflects the flexibility of the site, expressed by the Young's modulus $(E)$, which increases with charge (see explanation in text). Vertical offsets reflect the electrostatic penalty incurred by the mismatch in charge between the substituent cation and the site, calculated from Wood and Blundy's (2001) electrostatic model. Horizontal offsets between the parabola reflect decreasing $r_{0}$ with increasing charge. constrained melt compositions, $P-T-X$ conditions and the absence of experimentally derived partitioning data for agpaitic systems. Nevertheless, the models provide a tool to predict partitioning behaviour of heavy and light REE onto the various sites in the EGM structure, and how this behaviour might change as a function of EGM crystal chemistry.

For heterovalent substitutions, in this case trivalent REE substituting for divalent, univalent or tetravalent cations, various electrostatic penalties are incurred by the mismatch in charge which need to be accounted for in the lattice strain models. As summarised in Wood and Blundy (2014), substituent charge $(Z)$ considerably affects lattice strain partitioning curves, as $D_{0}$, $r_{0}$ and $E$ are all found to vary with valence. Firstly, $D_{0}$ decreases with increasing charge offset, due to the additional work required to offset the imbalance (Wood and Blundy, 2001). For most minerals, the charge-dependence of $D_{0}$ is found to be nearparabolic, and can be quantified by the electrostatic model of Wood and Blundy (2001):

$$
\frac{D_{0(M)}^{n+}}{D_{00(M)}}=\exp \left\{\frac{-4 \pi \mathrm{N}_{\mathrm{A}} e_{0}^{2}\left(Z_{n}-Z_{0(M)}\right)^{2}}{2 \varepsilon \mathrm{R} T}\right\}
$$

where $\varepsilon$ is charge on the electron. Following this equation, excess charge and deficit charge are penalised equally, such that $D_{0}^{2+}>D_{0}^{3+} \approx D_{0}^{1+}$ (Wood and Blundy, 2001). In our models, this amounts to an equal vertical offset in $D_{\mathrm{i}} / D_{\mathrm{o}}$ for isovalent and trivalent elements that substitute onto a divalent site, as shown in the schematic diagram of Fig. 7.

The second effect of charge is that the zero strain radius of a site decreases with increasing charge on the substituent element, i.e. $r_{0(M)}^{1+}>r_{0(M)}^{2+}>r_{0(M)}^{3+}$ (Wood and Blundy, 2014). The extent to which $r_{0}$ decreases with increasing charge varies per mineral, and can be substantial $(>0.1-0.2 \AA$ per $\Delta Z)$ as observed for octahedral Ca sites in wollastonite (Law et al., 2000) or relatively minor $(<0.03 \AA$ per $\Delta Z)$, as observed for $\mathrm{Ca}$ on the $M 2$ site in diopside (Wood and Blundy, 1997). The magnitude of this offset depends on mineral composition, bulk properties, $P T$ conditions, and a mineral's capacity to balance charge by coupled substitutions on nearest-neighbour sites. Given the complex solidsolution schemes and charge-balancing substitutions possible in EGM, we assume a relatively small charge dependence of $r_{0}$ for the considered sites. As such, we approach this charge effect by using $\Delta r_{0}$ values similar to that observed for the octahedral Ca-occupied M2 site in diopside by Wood and Blundy (1997), as follows: $r_{0}^{3+}=r_{0}^{2+}-0.01 \AA$ and $r_{0}^{1+}=r_{0}^{2+}+0.03 \AA$.

The third effect of charge on the substituent is that the effective Young's modulus of the site increases with increasing charge, 
i.e. $E_{M}^{1+}<E_{M}^{2+}<E_{M}^{3+}$. Again, we can use fig. 5 in Blundy and Wood (2003) to estimate Young's moduli from the $z / d^{3}$ ratios for each isovalent series of elements. The resulting theoretical partitioning curves, which take into account effects of charge on $D_{0}$, $r_{0}$ and $E$ (Fig. 7), are calculated using equation 1 and 2 and shown in Fig. 8. Elements are projected onto the isovalent partitioning curves for each of the considered sites. Young's moduli and site parameters used to calculate the curves are summarised in Table 6. The full calculation sheet is provided in Table S5.

A moderate Young's modulus for the Ca-dominated M1 site allows it to accommodate a wide range of substituents whose 6-fold radii are close to $\mathrm{Ca}$ such as $\mathrm{Y}$ and the lanthanides (Shannon, 1976). The $N$ site has an ideal charge of +1 and is highly flexible, but the lanthanides are relatively small and trivalent, and so partitioning onto this site is generally unfavoured (Fig. 8). The charge offset between $R E E^{3+}$ and $\mathrm{Zr}^{4+}$ is the same as that between $R E E^{3+}$ and $\mathrm{Ca}^{2+}$, which we here assume is equally penalised in terms of the electrostatic strain imposed on the structure (fig. 7 in Blundy and Wood, 2003). However, the Young's modulus of the $Z$ site would be large, making it relatively stiff and thus intolerant of any cation that does not match the size and charge of 6-fold $\mathrm{Zr}$ (Fig. 8).

The partitioning models allow us to extrapolate the partitioning behaviour of the other lanthanides and trace elements whose coordination states and bonding environment we have not directly measured (Fig. 8). In 6-fold coordination, the larger trivalent lanthanides, $\mathrm{La}^{3+}$ and $\mathrm{Ce}^{3+}$, are closer in radius to $\mathrm{Ca}^{2+}$ (Shannon, 1976) and hence it is reasonable to infer that they are most likely to substitute on the $M 1$ site. The smallest of the lanthanides, $\mathrm{Lu}^{3+}$, has an ionic radius of $0.86 \AA$ (Shannon, 1976), which is equally different from ${ }^{\mathrm{VI}} \mathrm{Ca}^{2+}(1 \AA)$ as from ${ }^{\mathrm{VI}} \mathrm{Zr}^{2+}(0.72 \AA)$. However, because of the substantial differences in Young's moduli and zero strain radius between the $M 1$ and $Z$ site, the $M 1$ site is more tolerant of the radius imbalance than the $Z$ site. Hence on the basis of lattice strain theory, we infer that even the smallest lanthanides will most favourably substitute for Ca onto M1. Conversely, only the highly charged and much smaller $\mathrm{Hf}^{4+}, \mathrm{Ti}^{4+}$ and $\mathrm{Nb}^{5+}(0.71,0.67$, and $0.64 \AA$ in 6-fold coordination) are likely to replace $\mathrm{Zr}$ on the $Z$ site (Fig. 8). This is consistent with XRD-based site allocations for these elements and the existence of EGM species where $\mathrm{Ti}$ dominates the $Z$-site (alluaivite) (Johnsen and Grice, 1999; Rastsvetaeva, 2007; Pfaff et al., 2010).

Using structural parameters derived from XRD from other species of EGM, we can also predict changes in REE partitioning behaviour as a function of EGM crystal chemistry. In the oneillite subgroup, half the $M 1$ octahedra are occupied by $\mathrm{Mn}$ or $\mathrm{Fe}$ (Table 1) creating an ordered structure of alternating larger $\mathrm{Ca}-$ $M 1$ sites and smaller $\mathrm{Mn}-\mathrm{M} 1$ sites. We can construct a lattice strain model for an oneillite-type EGM (Fig. 9) which partitions REE over the larger $\mathrm{Ca}$ and smaller $\mathrm{Mn}$ sites. Six-fold $\mathrm{Mn}$ $(0.83 \AA)$ is slightly smaller than Lu $(0.86 \AA)$, and so is much closer in radius to the heavy REE than $\mathrm{Ca}$. Therefore, when the $M 1$ site is structurally occupied by $\mathrm{Mn}$, substitution by the heaviest $R E E$ would impose significantly less elastic strain on the lattice than substitution by light REE (Fig. 9). Therefore, EGM species of the oneillite subgroup are likely to show a significant increase in the partitioning of heavy over light REE than EGM of the eudialyte subgroup, where Ca occupies all six $M 1$ octahedra. The REE profiles interpolated from our elastic strain model estimated partition coefficients for eudialyte s.s. and oneillite are shown in Fig. 10. On the basis of the partitioning curves in Fig. 8 eudialyte s.s. is expected to have a chondrite-normalised REE pattern that

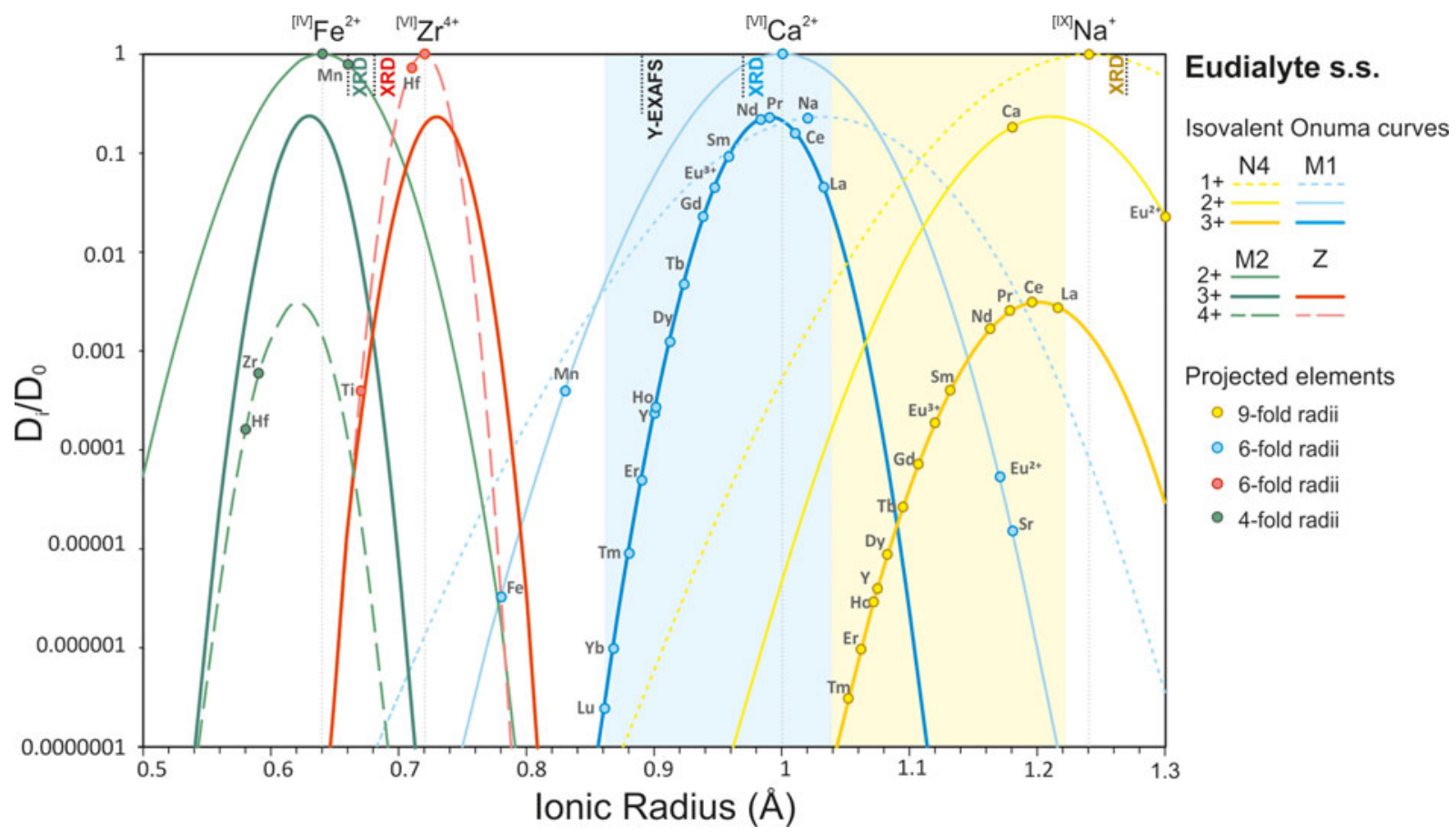

Fig. 8. Relative Onuma curves calculated for the $N 4, M 1, M 2$ and $Z$ sites in eudialyte s.s. (Johnsen and Grice, 1999). $D_{\mathrm{i}} / D_{0}$ are calculated from the lattice strain model of Blundy and Wood (1994) using $r_{0}$ values that correspond to the radii of the dominant cation on the site. Thick stippled lines indicate EXAFS- and XRD-determined site dimensions (bond distance minus $1.38 \AA$ radius of oxygen, Table 6$)$ that could be taken as alternative zero strain radii $\left(r_{0}\right)$ for the sites. Note variations in the horizontal and vertical positions, as well as the tightness of the parabolas with valency, due to charge effects on $E_{\mathrm{S}}, r_{0}$ and $D_{0}$, as summarised in Fig. 7 . Input parameters for each site are given in Table 6. 


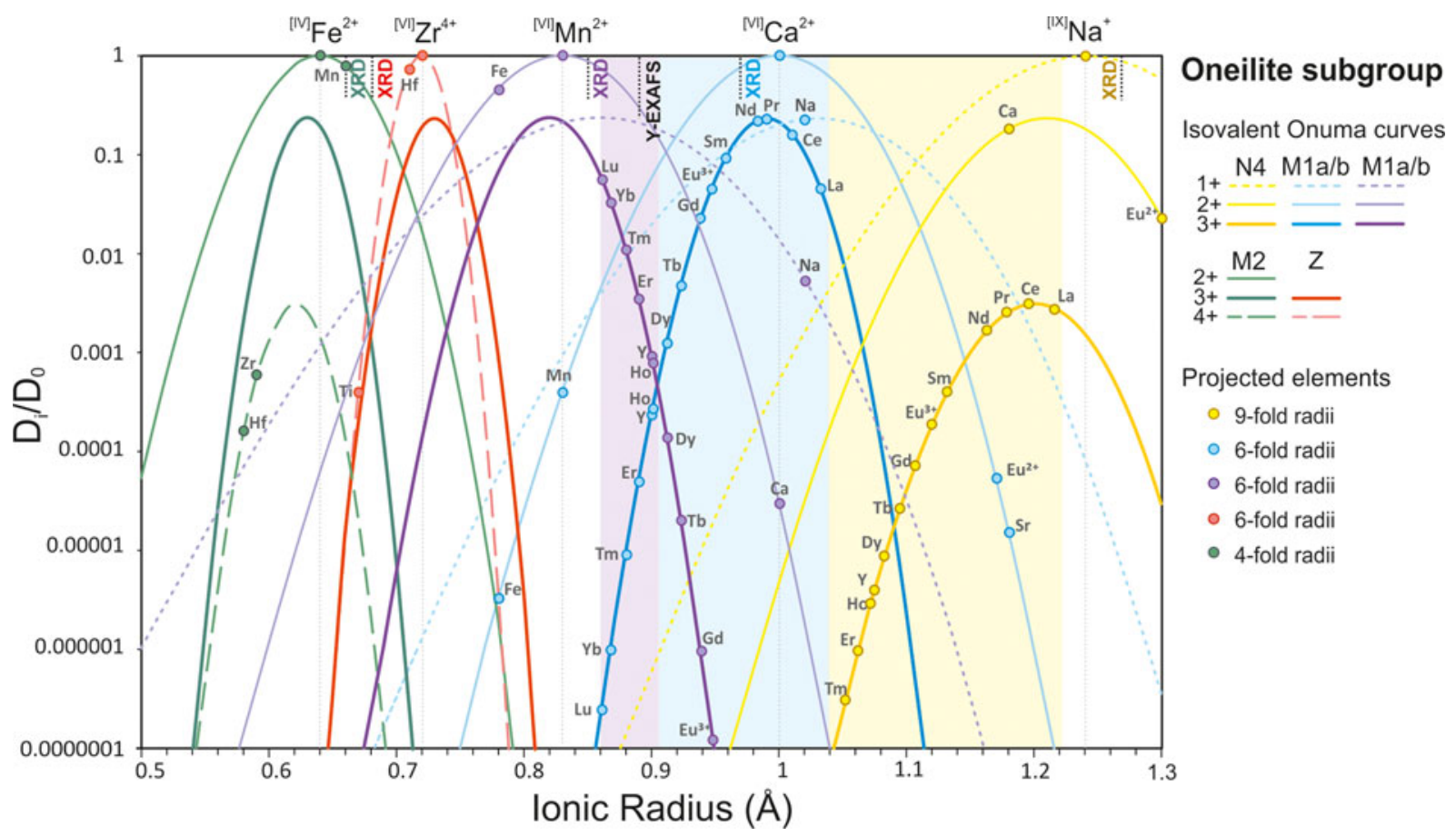

Fig. 9. Relative Onuma curves calculated for the $N 4, M 1, M 2$ and $Z$ sites in oneillite subgroup members, where $M 1$ octahedral rings consist of two non-equivalent subsites (M1a and b) which are occupied by $\mathrm{Ca}, \mathrm{Na}, \mathrm{Mn}$, or Fe (Table 1). The example shown is for oneillite, Mn-raslakite and (Ca-Mn)-ordered eudialyte, where one of the $M 1$ subsites is predominantly occupied by $\mathrm{Mn}$, and the other by $\mathrm{Ca}$, as in eudialyte s.s. For further explanation of diagram see the caption of Fig. 8 .

strongly favours light REE over heavy (particularly Ce-Pr-Nd), whereas oneillite gives a profile that favours the smallest $H R E E$ as well as the larger LREE, and thus becomes relatively flat across the whole $R E E$ series. The sinusoidal profile interpolated from an oneillite-type substitution model is closer to the relatively flat $R E E$ patterns observed in natural EGM (Fig. 10). Our EXAFS data are insufficient to allow refinement of the occupancy of the Ca site to explore the hypothesis that HREE such as Y are clustered with Mn in oneillite-type microdomains. Nevertheless we hypothesise that clustering of $\mathrm{Mn}$ and heavy REE on $M 1$ subsites in eudialyte s.s. gives rise to relatively flat to $H R E E$ enriched $R E E$ profiles. We conclude that EGM crystal chemistry and symmetry, in particular that of $\mathrm{Ca}$ and Mn content of the M1 site, plays an important role in $R E E$ partitioning behaviour and the capacity of EGM to fractionate light and heavy REE in the melt or fluids from which they crystallise.

\section{Summary and conclusions}

We studied the substitution of rare earth elements in eudialytegroup minerals (EGM) using X-ray absorption spectroscopy. Yttrium $\mathrm{K}$-edge and $\mathrm{Nd} \mathrm{L}_{3}$-edge XANES and EXAFS were collected for EGM from Ilímaussaq, Narsaarsuk, Norra Kärr, Kipawa and Lovozero and compared to absorption spectra for $R E E$-bearing silicates, fluorides, phosphates and solutions. The EGM spectra exhibit reproducible XANES for $\mathrm{Nd}$, as well as for $\mathrm{Y}$, indicating consistent site occupancies for light REE and for heavy REE in EGM of varying composition and provenance. Yttrium $K$-edge XANES for EGM are unlike any of the measured standards and thus suggest a unique structural configuration. However, the EGM Y K-XANES share a characteristic feature (i.e. broad peak at $17,110 \mathrm{eV}$ ) with the standards in which the $R E E$ are inferred to occupy 6 -fold coordinated sites. The $\mathrm{Nd}$
$L_{3}$-XANES for EGM are similar to those measured for the standards, and lack unique features that reflect the coordination state of $\mathrm{Nd}$.

Quantitative refinement of the $\mathrm{Y} K$-EXAFS suggests that yttrium dominantly substitutes for calcium on the crystallographic $M 1$ site. Single-shell refinements yield optimal fits for Y in 6-fold coordination with $\mathrm{Y}-\mathrm{O}$ bond distances between 2.24$2.32 \AA$. These bond distances correspond to a $3 \%$ contraction relative to ideal bond distances (XRD-determined, $r_{\mathrm{o}}$ ) in the $\mathrm{Ca}^{2+}$-dominant $M 1$ site. The second coordination sphere in the EXAFS spectrum is successfully fitted to $2 \mathrm{Na}, 1 \mathrm{Fe}, 6 \mathrm{Si}, 2 \mathrm{Ca}$

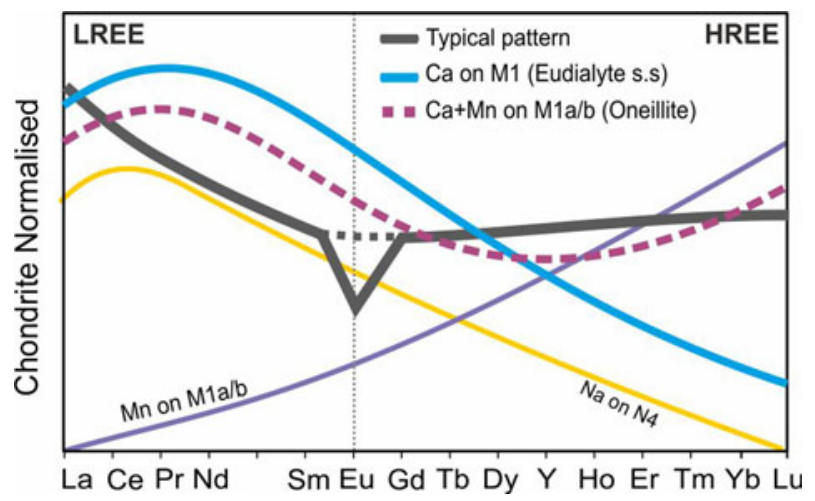

Fig. 10. Projected chondrite-normalised REE patterns based on lattice strain partitioning models for eudialyte s.s. and oneillite-subgroup variations on the $M 1$ site, as shown in Fig. 8 and 9. Note that melt compositions and absolute partitioning coefficients are unknown, and so the patterns are purely theoretical. Typical REE patterns for eudialyte-group minerals observed in nature are slightly $L R E E$ enriched with flat HREE patterns, with or without Eu anomalies. Europium anomalies are neglected in projected patterns, and depend on parental melt signatures (Schilling et al., 2011). 
and $4 \mathrm{O}$, present at an average distance of $3.5 \AA$ to the $M 1$ site. Our XAS refinements exclude preferential substitution of the smaller heavy REE onto the smaller octahedral $Z$ site (typical $\mathrm{Zr}$-O distances of $2.08 \AA$ ), as well as the larger polyhedral $N$ site (average $\mathrm{Na}-\mathrm{O}$ distances of $2.54 \AA$ ). We support our results using theoretical partitioning diagrams (Onuma curves) calculated using lattice strain theory on the basis of the ideal charge and size of the sites. These models predict that even the smallest lanthanides (HREE) are favoured on the octahedral M1 site, and that the relative partition coefficients of the heavy $R E E$ increase significantly relative to the light $R E E$ when Mn or Fe occupy a significant proportion of the $M 1$ octahedral rings (e.g. in the Ca-deficient oneillite subgroup). Our data indicate that the relatively flat to $H R E E$-enriched profiles that make eudialyte an attractive exploration target are not the result of heavy and light $R E E$ partitioning onto different structural sites. Rather we infer that ordering in $M 1$ or coupling of $H R E E$ with smaller ions such as Mn produces the characteristically flat REE patterns observed in natural EGM.

Acknowledgements. This work was carried out under the NERC-funded SOS RARE consortium [grant NE/M010856/1 to AMB, NJH and AF]. We thank Diamond Light Source and KIT Karlsruhe Light Source for beam time at I18 [grants SP14793 and SP15903] and SUL-X, respectively. PG was funded by the People Programme (Marie Curie Actions) in the EU Seventh Framework Programme (FP7/2007-2013), REA grant agreement no. 609405 (COFUNDPostdocDTU), and wishes to dedicate this contribution to the memory of Dr Takeshi Kasama, his late mentor at the Center for Electron Nanoscopy. We thank Chris Hayward for assistance with EMPA analyses, Martin Smith, Peter Nason and Athanasios Godelitsas for assistance at I18 and SUL-X and Charlie Beard for discussions on lattice strain models. We thank the Geological Survey of Denmark and Greenland, Lynn Boatner (ORNL, USA), National Museum Scotland, the Hunterian Museum and SOSRARE partners for providing samples and standards. We thank three anonymous reviewers for constructive reviews and Roger Mitchell and Helen Kerbey for editorial handling.

Supplementary material. To view supplementary material for this article, please visit https://doi.org/10.1180/mgm.2019.50

\section{References}

Adamas Intelligence (2019) Rare Earth Elements: Market Issues and Outlook. R. Castilloux, editor, Adamas Intelligence Report Q2, pp. 1-9.

Balomenos E., Davris P., Deady E., Yang J., Panias D., Friedrich B., Binnemans K., Seisenbaeva G., Dittrich C., Kalvig P. and Paspaliaris I. (2017) The EURARE Project: development of a sustainable exploitation scheme for Europe's rare earth ore deposits. Johnson Matthey Technology Review, 61, 142-153.

Binnemans K., Jones P.T., Müller T. and Yurramendi L. (2018) Rare earths and the balance problem: how to deal with changing markets? Journal of Sustainable Metallurgy, 4, 126-146.

Blundy J. and Wood B. (1994) Prediction of crystal-melt partition coefficients from elastic moduli. Nature, 372, 452.

Blundy J. and Wood B. (2003) Partitioning of trace elements between crystals and melts. Earth and Planetary Science Letters, 210, 383-397.

Boatner L.A. (2002) Synthesis, structure, and properties of monazite, pretulite, and xenotime. Pp. 87-121 in: Phosphates (M.L. Kohn, J. Rakovan and J.M. Hughes, editors). Reviews in Mineralogy \& Geochemistry, 48. Mineralogical Society of America and the Geochemical Society, Chantilly, Virginia, USA.

Borst A.M., Friis H., Andersen T., Nielsen T.F.D., Waight T.E. and Smit M.A. (2016) Zirconosilicates in the kakortokites of the Ilímaussaq complex, South Greenland: Implications for fluid evolution and high-field-strength and rare-earth element mineralization in agpaitic systems. Mineralogical Magazine, 80, 5-30.
Borst A.M., Friis H., Nielsen T.F.D. and Waight T.E. (2018) Bulk and mush melt evolution in agpaitic intrusions: insights from compositional zoning in eudialyte, Ilímaussaq Complex, South Greenland. Journal of Petrology, 59, 589-612.

Brice J.C. (1975) Some thermodynamic aspects of the growth of strained crystals. Journal of Crystal Growth, 28, 249-253.

Chakhmouradian A.R. and Wall F. (2012) Rare earth elements: minerals, mines, magnets (and more). Elements, 8, 333-340.

Davris P., Stopic S., Balomenos E., Panias D., Paspaliaris I. and Friedrich B. (2017) Leaching of rare earth elements from eudialyte concentrate by suppressing silica gel formation. Minerals Engineering, 108, 115-122.

de Groot F.M.F. (1995) Differences between $\mathrm{L}_{3}$ and $\mathrm{L}_{2} \mathrm{X}$-ray absorption spectra. Physica B: Condensed Matter, 208-209, 15-18.

Díaz-Moreno S., Muñoz-Páez A. and Chaboy J. (2000) X-ray Absorption Spectroscopy (XAS) study of the hydration structure of yttrium(III) cations in liquid and glassy states: Eight or nine-fold coordination? Journal of Physical Chemistry A, 104, 1278-1286.

Downs R.T. and Hall-Wallace M. (2003) The American Mineralogist crystal structure database. American Mineralogist, 88, 247-250.

Dura O.J., Boada R., López de la Torre M.A., Aquilanti G., Rivera-Calzada A., Leon C. and Chaboy J. (2013) XANES and EXAFS study of the local order in nanocrystalline yttria-stabilized zirconia. Physical Review B, 87, 174109.

Estrade G., Salvi S., Béziat D., Rakotovao S. and Rakotondrazafy R. (2014) REE and HFSE mineralization in peralkaline granites of the Ambohimirahavavy alkaline complex, Ampasindava peninsula, Madagascar. Journal of African Earth Sciences, 94, 141-155.

Estrade G., Salvi S. and Béziat D. (2018) Crystallization and destabilization of eudialyte-group minerals in peralkaline granite and pegmatite: a case study from the Ambohimirahavavy complex, Madagascar. Mineralogical Magazine, 82, 375-399.

European Commission (2017) Study on the Review of the List of Critical Raw Materials - Final Report. European Union, Luxembourg.

Finch A.A. and Allison N. (2007) Coordination of $\mathrm{Sr}$ and $\mathrm{Mg}$ in calcite and aragonite. Mineralogical Magazine, 71, 539-552.

Finck N., Bouby M., Dardenne K. and Yokosawa T. (2017) Yttrium co-precipitation with smectite: A polarized XAS and AsFlFFF study. Applied Clay Science, 137, 11-21.

Friis H. (2009) Luminescence Spectroscopy of Natural and Synthetic REE-Bearing Minerals. PhD Thesis, University of St Andrews, St Andrews, UK.

Friis H., Finch A.A., Williams C.T. and Hanchar J.M. (2010) Photoluminescence of zircon $(\mathrm{ZrSiO} 4)$ doped with $R E E 3+(R E E=\mathrm{Pr}$, Sm, Eu, Gd, Dy, Ho, Er). Physics and Chemistry of Minerals, 37, 333-342.

Fryer B. and Edgar A. (1977) Significance of rare earth distributions in coexisting minerals of peralkaline undersaturated rocks. Contributions to Mineralogy and Petrology, 61, 35-48.

Goodenough K., Schilling J., Jonsson E., Kalvig P., Charles N., Tuduri J., Deady E., Sadeghi M., Schiellerup H. and Müller A. (2016) Europe's rare earth element resource potential: An overview of REE metallogenetic provinces and their geodynamic setting. Ore Geology Reviews, 72, 838-856.

Goodenough K.M., Wall F. and Merriman D. (2017) The rare earth elements: demand, global resources, and challenges for resourcing future generations. Natural Resources Research, 1-16.

Grice J.D. and Gault R.A. (2006) Johnsenite-(CE): A new member of the eudialyte group from Mont Saint-Hilaire, Quebec, Canada. The Canadian Mineralogist, 44, 105-115.

Guiseppetti G., Mazzi F. and Tadini J. (1971) The crystal structure of eudialyte. Tschermaks mineralogische und petrographische Mitteilungen, 16, 105-127.

Hatch G.P. (2012) Dynamics in the global market for rare earths. Elements, 8, 341-346.

Hazen RM and Finger LW (1979) Bulk-modulus-volume relationship for cation-anion polyhedra. Journal of Geophysics Reserach, 84, 6723-6728

Johnsen O. and Grice J.D. (1999) The crystal chemistry of the eudialyte group. The Canadian Mineralogist, 37, 865-891.

Johnsen O., Grice J.D. and Gault R.A. (1999) Oneillite; a new Ca-deficient and REE-rich member of the eudialyte group from Mont Saint-Hilaire, Quebec, Canada. The Canadian Mineralogist, 37, 1295-1301.

Johnsen O., Grice J.D. and Gault R.A. (2001) The eudialyte group: a review. Geology of Greenland Survey Bulletin, 190, 65-72. 
Johnsen O., Ferraris G., Gault R.A., Grice J.D., Kampf A.R. and Pekov I.V. (2003) The nomenclature of eudialyte-group minerals. The Canadian Mineralogist, 41, 785-794.

Kanno H. and Hiraishi J. (1984) Raman study of aqueous rare earth nitrate solutions in liquid and glassy states. The Journal of Physical Chemistry, 88, 2787-2792.

Law K.M., Blundy J.D., Wood B.J. and Ragnarsdottir K.V. (2000) Trace element partitioning between wollastonite and silicate-carbonate melt. Mineralogical Magazine, 64, 651-661.

Lazdins K. and Kuzmin A. (2015) Local structure and lattice dynamics of cubic $\mathrm{Y}_{2} \mathrm{O}_{3}$ : an $\mathrm{x}$-ray absorption spectroscopy study. IOP Conference Series: Materials Science and Engineering: IOP Publishing, 012031.

Liu W., Etschmann B., Migdisov A., Boukhalfa H., Testemale D., Müller H., Hazemann J.-L. and Brugger J. (2017) Revisiting the hydrothermal geochemistry of europium (II/III) in light of new in situ XAS spectroscopy results. Chemical Geology, 459, 61-74.

Machacek E. and Kalvig P. (2016) Assessing advanced rare earth elementbearing deposits for industrial demand in the EU. Resources Policy, 49, 186-203.

Mariano A.N. and Mariano Jr A. (2012) Rare earth mining and exploration in North America. Elements, 8, 369-376.

Marks M.A.W. and Markl G. (2017) A global review on agpaitic rocks. Earth-Science Reviews, 173, 229-258.

Mitchell R.H. and Liferovich R.P. (2006) Subsolidus deuteric/hydrothermal alteration of eudialyte in lujavrite from the Pilansberg alkaline complex, South Africa. Lithos, 91, 352-372.

Möller V. and Williams-Jones A.E. (2016) Petrogenesis of the Nechalacho Layered Suite, Canada: magmatic evolution of a REE-Nb-rich nepheline syenite intrusion. Journal of Petrology, 57, 229-276.

Möller V. and Williams-Jones A.E. (2017) Magmatic and hydrothermal controls on the mineralogy of the basal zone, Nechalacho REE-Nb-Zr deposit, Canada. Economic Geology, 112, 1823-1856.

Mosselmans J.F.W. Quinn, P.D. DentA.J., Cavill S.A., Moreno S.D., Peach A., Leicester P.J., Keylock S.J., Gregory S.R., Atkinson K.D. and Rosell J.R. (2009) I18 - the microfocus spectroscopy beamline at the Diamond Light Source. Journal of Synchrotron Radiation, 16, 818-824.

Newville M. (2001) IFEFFIT: interactive XAFS analysis and FEFF fitting. Journal of Synchrotron Radiation, 8, 322-324.

Ni Y., Hughes J.M. and Mariano A.N. (1995) Crystal chemistry of the monazite and xenotime structures. American Mineralogist, 80, 21-26.

Paulick H. and Machacek E. (2017) The global rare earth element exploration boom: An analysis of resources outside of China and discussion of development perspectives. Resources Policy, 52, 134-153.

Persson I., D’Angelo P., De Panfilis S., Sandström M. and Eriksson L. (2008) Hydration of lanthanoid (III) ions in aqueous solution and crystalline hydrates studied by EXAFS spectroscopy and crystallography: The myth of the "gadolinium break". Chemistry - A European Journal, 14, 3056-3066.

Pfaff K., Krumrei T., Marks M., Wenzel T., Rudolf T. and Markl G. (2008) Chemical and physical evolution of the 'lower layered sequence' from the nepheline syenitic Ilímaussaq intrusion, South Greenland: Implications for the origin of magmatic layering in peralkaline felsic liquids. Lithos, 106, 280-296.

Pfaff K., Wenzel T., Schilling J., Marks M. and Markl G. (2010) A fast and easy-to-use approach to cation site assignment for eudialyte group minerals. Neues Jahrbuch fur Mineralogie, 187, 69-81.

Rastsvetaeva R. (2007) Structural mineralogy of the eudialyte group: A review. Crystallography Reports, 52, 47-64.

Rastsvetaeva R.K. and Chukanov N.V. (2012) Classification of eudialyte-group minerals. Geology of Ore Deposits, 54, 487-497.
Rastsvetaeva R., Aksenov S. and Chukanov N. (2010) Crystal structure of the $\mathrm{Mn}$ analogue of raslakite, a new representative of the eudialyte group. Doklady Chemistry, 76-81.

Rastsvetaeva R.K., Aksenov S.M. and Rozenberg K.A. (2015) Crystal structure and genesis of the hydrated analog of rastsvetaevite. Crystallography Reports, 60, 831-840.

Rastsvetaeva R.K., Rozenberg K.A., Chukanov N.V. and Aksenov S.M. (2017) Crystal structure of ilyukhinite, a new mineral of the eudialyte group. Crystallography Reports, 62, 60-65.

Ravel B. and Newville M. (2005) ATHENA, ARTEMIS, HEPHAESTUS: data analysis for X-ray absorption spectroscopy using IFEFFIT. Journal of Synchrotron Radiation, 12, 537-541.

Roskill (2018) Rare Earths, Global Industry, Market and Outlooks 2018. London, United Kingdom.

Santos C., Strecker K., Suzuki P., Kycia S., Silva O. and Silva C. (2005) Stabilization of $\alpha$-SiAlONs using a rare-earth mixed oxide (RE2O3) as sintering additive. Materials Research Bulletin, 40, 1094-1103.

Schilling J., Wu F.-Y., McCammon C., Wenzel T., Marks M.A.W., Pfaff K., Jacob D.E. and Markl G. (2011) The compositional variability of eudialyte-group minerals. Mineralogical Magazine, 75, 87-115.

Shannon R.D. (1976) Revised effective ionic radii and systematic studies of interatomic distances in halides and chalcogenides. Acta Crystallographica A, 32, 751-767.

Sjöqvist A.S., Cornell D.H., Andersen T., Erambert M., Ek M. and Leijd M. (2013) Three compositional varieties of rare-earth element ore: eudialytegroup minerals from the Norra Kärr Alkaline Complex, Southern Sweden. Minerals, 3, 94-120.

Smith M.P., Moore K., Kavecsánszki D., Finch A.A., Kynicky J. and Wall F. (2016) From mantle to critical zone: A review of large and giant sized deposits of the rare earth elements. Geoscience Frontiers, 7, 315-334.

Stark T., Silin I. and Wotruba H. (2016) Mineral processing of eudialyte ore from Norra Kärr. Journal of Sustainable Metallurgy, 3, 32-38.

Stromeyer F. (1819) Summary of Meeting 16 December 1819. Gottingische gelehrte Anzeigen, 3, 1993-2000.

Tanaka K., Takahashi Y. and Shimizu H. (2008) Local structure of Y and Ho in calcite and its relevance to $\mathrm{Y}$ fractionation from Ho in partitioning between calcite and aqueous solution. Chemical Geology, 248, 104-113.

Tanaka K., Takahashi Y. and Shimizu H. (2009) Determination of the host phase of rare earth elements in natural carbonate using X-ray absorption near-edge structure. Geochemical Journal, 43, 143-149.

van de Ven M.A.J., Borst A.M., Davies G.R., Hunt E.J. and Finch A.A. (2019) Hydrothermal alteration of eudialyte-hosted critical metal deposits: fluid source and implications for deposit grade. Minerals, 9, 422.

Voßenkaul D., Birich A., Müller N., Stoltz N. and Friedrich B. (2017) Hydrometallurgical processing of eudialyte bearing concentrates to recover rare earth elements via low-temperature dry digestion to prevent the silica gel formation. Journal of Sustainable Metallurgy, 3, 79-89.

Wood B.J. and Blundy J.D. (1997) A predictive model for rare earth element partitioning between clinopyroxene and anhydrous silicate melt. Contributions to Mineralogy and Petrology, 129, 166-181.

Wood B.J. and Blundy J.D. (2001) The effect of cation charge on crystal-melt partitioning of trace elements. Earth and Planetary Science Letters, 188, 59-71.

Wood B.J. and Blundy J.D. (2014) Trace element partitioning: the influences of ionic radius, cation charge, pressure, and temperature. Pp. 421-448 in: Treatise on Geochemistry (Second Edition) (H.D. Holland and K.K. Turekian, editors). Elsevier, Oxford, UK.

Wyckoff R.W.G. (1964) Crystal Structures. Krieger, New York. 